Ummanel, A.. (2017). Kum ve Oyun Alanları Üzerine Bir İnceleme. Abant İzzet Baysal Üniversitesi Eğitim Fakültesi Dergisi, 17 (3), 1539-1566.

Geliș Tarihi: 22/02/2017

Kabul Tarihi:14/08/2017

\title{
KUM VE OYUN ALANLARI ÜZERINE BİR İNCELEME
}

\author{
Azize UMMANEL*
}

\section{ÖZET}

Dışarı oyun alanlarının çocuğun gelişim alanlarını destekleyici şekilde düzenlenmesine yönelik gerek ülkemizde gerekse dünyada çeşitli çalışmalar yapılmakta; bu alanların kullanımına yönelik çocuğa zarar vermeyen malzemelerin kullanılmasına dikkat edilmektedir. Kuşkusuz bu malzemelerden birisi de çocuğun yaratıcıllı̆ını, küçük kas becerilerini, sosyal ve zihinsel gelişimini destekler nitelikte olan kumdur. Bu çalışmanın amacı kum havuzlarının önemine dair yapılan çalışmalardan birisi olan ve yabancı bir dilden Osmanlıcaya çevirisi yapılan Kumlarda Çocuk Oyunları adlı kitabın incelenmesi ve kumun bir eğitim aracı olarak kullanılması üzerine değerlendirmeler yapılmasıdır. Nitel bir çalıșma olan bu araştırmada veriler doküman analizi yöntemi kullanılarak çözümlenmiştir. Elde edilen bulgular göstermektedir ki yaklaşık yüz yıl öncesinde Osmanlı aydınlarının çocukluğa bakışının onların korunma, temiz hava ve oyun haklarına sahip bireyler olduğu; kumun bir eğitim aracı olarak kullanılması gerektiği, keza kum oyunlarının çocuğun gelişimi açısından fayda sağladığı ve onun gelişim alanlarını desteklediği; öte yandan ekonomik bir eğitim aracı olan kumun, oyun alanlarını yeniden düzenleyerek, kum masaları ve kum havuzları oluşturularak etkili bir şekilde kullanılabileceği yönündedir. Fakat zamanla kum havuzlarının ortadan kaldırıldığı ve göz ardı edildiği, bir eğitim aracı olarak verilen önemin azaldığını görülmektedir. Bu hususta yeni düzenlemeler yapılarak kum oyunlarının eğitimde daha aktif bir şekilde kullanılması öneriler arasında yer almaktadır.

Anahtar Kelimeler: Çocuk, kum, oyun alanları, eğitim

\section{AN EXPLORATION ON SAND AND PLAYGROUNDS}

\begin{abstract}
Many studies that are oriented at constructing outdoor playgrounds in a manner to support children's developmental areas are being carried out both in our country and throughout the world and with respect to the use of these areas, care is being taken to use materials that will not harm children. Certainly, one of these materials is sand, which supports the creativity, fine motor skills and the social development of children. The purpose of this study is to analyze the book Children's Games on Sand, which was translated from a foreign language to Ottoman and was one of the studies carried out on the importance of sand pits. In this qualitative study, document analysis was used to analyze the data. Findings show that Ottoman intellectuals thought that children are individuals who need protection and fresh air, and have the right to play; and sand has to be used as an educational tool, since sand games are beneficial for the children's development and support their developmental areas; sand, as an economic, educational tool, can be used effectively by reconstructing playgrounds, constructing sand tables and sand pits. However, we see that in time, sand pits have been removed and ignored and that the importance assigned to these as educational tools has declined. The preparation of new regulations on this subject and the use of sand games in education more actively can be listed as suggestions.
\end{abstract}

Keywords: Child, sand, playgrounds, education

* Lefke Avrupa Üniversitesi, Dr. Fazıl Küçük Eğitim Fakültesi, Okul Öncesi Öğretmenliği Bölümü, azizeummanel@yahoo.co.uk 


\section{GíRiş}

Çocuktan ayrı düşünülemeyen oyun kavramı, oyun ile ilgili çalışmalar yapan birçok araştırmacı tarafından farklı şekillerde ele alınmış ve tanımlanmıştır. Egemen, Yılmaz ve Akil (2004) oyun kavramını çocuğun hiçbir baskı altından kalmadan kendi isteği ile giriştiği etkinlikler olarak tanımlarken, Ulutaş (2011) oyunu kendi içerisinde bir bütünlüğü olan, belli bir sıra ve mantık olmaksınız, çatışmalardan uzak, özgür bir ortamda kendiliğinden gelişen eğlenceli ve içten güdümlü bir etkinlik olarak nitelendirmektedir. Susüzer'e göre (2006) insan ilişkileri, yardımlaşma ve paylaşma gibi sosyal beceriler oyun yolu ile deneyimlenmektedir. Farklı bir şekilde Yörükoğlu (1987) oyunu, öğrenmeyi kamçılayan, zihinsel becerileri ve yaratıcılığı destekleyen bir etkinlik; Dirim (2000) ise duygu ve düşüncelerin ifade edildiği, zihinsel gelişimin yanı sıra bedensel ve duygusal gelişime de katkıda bulunan bir süreç olarak tanımlamışlardır. Daha kapsamlı bir şekilde belirtecek olursak "oyun, belli bir amaca yönelik ya da amaçsız olarak, kurallı ya da kuralsız, çocuğun tüm gelişim alanlarına etki eden, çocuğun isteyerek ve hoşlanarak katıldığı, araçlı ya da araçsız olarak gerçekleştirilenen doğal bir öğrenme aracıdır” (Koçyiğit, Tuğluk ve Kök, 2007, s. 327). Kısacası çocuğun en temel işi olarak görülen oyun, çocukta herhangi bir baskı olmaksızın kendiliğinden ortaya çıkan ve onun zihinsel, dil, sosyal, duygusal, motor gelişim ve özbakım becerileri olmak üzere tüm gelişim alanlarını etkileyen bir eylemler bütünüdür.

And (2012), oyunu günlük yaşama ara verme ve dinlenme olarak tanımlamaktadır. O’na göre oyun bir gelenek gibi sürekli tekrarlanmakla beraber, kendine özgü bir yerde başlar, bir sonuca odaklıdır ve belli bir noktada biter. Oyunun yer bakımından sınırları vardır ve dışarıdan içeriye belli kurallarla girilir; dolayısı ile içeride uyulması gereken belli kurallar vardır. Bu da oyunun kendine özgü bir düzen içerisinde gerçekleştiğinin göstergesidir ki bu düzeni bozanlar oyun dışına itilir. Öte yandan Singer (1994), tekrarlayıcı ve keşfedici özellikleri olan çocuk oyunlarının sadece eğlence amaçlı değil, aynı zamanda onların bilişsel ve duygusal becerilerinin gelişimi için önemli bir etken olduğunu savunmaktadır.

Başlarda tek başına oynayan çocuk, zamanla sosyalleşme süreci içerisinde arkadaşlarıyla işbirlikli oyunlar sergilemeye başlar. Bu oyunlar içeri mekanlarda olabileceği gibi dışarı oyun alanlarında da kendini göstermektedir. Öyle ki küçük yaşlarda evinde kendi başına veya aile bireyleri ile oyun oynayan çocuk, yaşı ilerledikçe sosyalleşme ihtiyacı duymakta ve oyun etkinliklerini dişarı alanlara taşıyarak yeni arkadaşlar edinmek isteyebilmektedir (Öztürk, 2015). Dışarı oyun alanları çocuğa doğa ile iç içe olabilme imkanı veren, yaratıcı gücünün ortaya çıkmasına katkıda bulunan ve bu anlamda zihinsel gelişimi destekleyen, ayrıca çocuğa birtakım egzersiz imkanları da sunan alanlardır (Türkan, 2009). Çocuk, dış mekanda oynayarak hem kendi yeteneklerini test eder, hem de dış mekanda devam eden günlük hayata ve yetişkin dünyasına adapte olma firsatını yakalar (Gökmen, 2006). Bununla birlikte oyun alanlarında yapılan koşma, tırmanma, sıçrama, sürünme gibi hareketler çocukların kas ve fiziksel gelişimini (Gül, 2006; Kaya, 2007); diğer çocuklarla aynı ortamda bulunma ve oyun oynama davranışı da sosyal gelişimi desteklemektedir (Yücel, 2005). Fanuscu (1994), oyunun kalitesini belirleyen etmenlerin oyun alanı ve oyun elemanlarının nitelikleri olduğunu savunmaktadır. Benzer bir şekilde Yücel (2005) de başarılı bir oyun alanının çocukların farklı ihtiyaçlarına ve fiziksel meydan okumalarına fırsatlar sunan alanlar olduğunu belirtmiştir.

Dışarı oyun alanları yapısı gereği çocuğun daha özgür hareket edebileceği ve motor becerilerinin en üst düzeyde desteklendiği oyun alanlarıdır. Bunun yanı sıra çocuğu çevre 
ile bütünleştiren aktivitelere yönlendirebilmekte; çocuk temiz havada aktivite yapma firsatı bulurken su, kum ve çamur gibi malzemeleri keşfederek birtakım yeni deneyimler de kazanabilmektedir.

Türkiye'de dışarı oyun alanları ile ilgili çalışmaların 1970li yıllardan itibaren yoğunlaştığını, genellikle peyzaj mimarları tarafindan yapıldığını ve hızla arttığını görmekteyiz (Çakırer Özservet, 2015a). Dışarı oyun alanlarının çocuğun gelişim alanlarını destekleyici şekilde düzenlenmesine yönelik gerek ülkemizde gerekse dünyada çeşitli çalışmalar bulunmakta; bu alanların kullanımına yönelik çocuğa zarar vermeyen malzemelerin kullanılmasına da dikkat edilmektedir. Bu alanda çalışan araştırmacılar çocuklar için oluşturulan alanların tehlikelerden uzak ve çocukların gelişim özelliklerine uygun olması gerektiğini savunmakta; bu çevrelerde çocuğa zarar verecek bitkilerin olmaması, sade ve basit oyun öğeleri ile donatılarak çocukların üzerinde dolaşıp rahatça oynayabilecekleri çim alanlar ve kum havuzu gibi doğal malzemelerin bulunması gerektiğini belirtmektedirler (Çukur, 2009; Özgüç Erdönmez, 2007; Zengin, 2001). Böylelikle dışarı oyun alanlarındaki uygun düzenlemeler ile çocuklara doğa bilinci de kazandırılabilmektedir (Çukur ve Özgüner, 2008). Çukur'a göre (2011), yetişkinler çocukların çevresel ihtiyaçlarını tam olarak anlayamadıkları için onların düşünce, istek ve gereksinimlerine göre bir çevre tasarımı yapamamakta ve bu durum çocuğun ona özel inşa edilen çevreye uyum sağlamasını zorlaştırmaktadır. Öyle ki Karaküçük (2008) yapmış olduğu bir çalışmada dış mekanlarda bahçe düzenlemesi, çiçek ve oyun materyallerine yeteri kadar yer verilmediğini saptamıştır. Oysaki yapılan bir başka çalışmada çocukların oyun materyallerinden ve dışarı oyun alanlarında yer alan kum havuzlarından oldukça hoşlandıkları bulunmuştur (Özgen, 1997).

Kum, toprak ve çamur gibi doğal malzemeler eski çağlardan beridir oyunlarda ve oyuncak yapımında kullanılmaktadır (And, 2012). Antik Yunan'a dayanan araştırmalar o dönemde kullanılan çok sayıda oyuncağın temel yapım malzemesinin pişmiş toprak olduğunu belirtmektedir (Şar, 2015). Hughes (2010), iki yaşındaki bir çocuğun bir oyun materyali olan kil ile tanıştırılabileceğini ve çocuğun kili ezmesi, sıkıştırması ve kalıp haline getirmesi sonucu duygularını keşfedebileceğini belirtmiştir. Kil gibi su ve kum oyunları da aynı etkiyi yaratabilecektir. Çocuk yaşı büyüdükçe ilgisi dahilinde bu materyaller ile vakit geçirmeye devam eder, fakat bu materyalleri kullanım şekli ve oyun şekli yaşı büyüdükçe farklılaşmakta, çocuk farkında olmadan yaratıcı sanat ürünleri ortaya koyabilmektedir.

Hughes (2010) çocukların tırmanma merdiveni, kaydıraklar ve kum havuzlarında birbirleri ile daha sık sosyal etkileşime girdiklerini; fakat yine de bu oyuncaklarda geçirdikleri zamanlarının büyük bir kısmını tek başına veya paralel oyun olarak geçirdiklerini belirtmiştir. Çocukların bu oyuncaklarda harcadıkları toplam sürenin sadece yüzde beşlik bir kısmında sosyo-dramatik oyunlar oynadıkları gözlenmiş̧ir.

Yabancı literatürde kum ile ilgili birbirinden farklı çalışmalara rastlamak mümkündür. Türkiye'de yapılan çalışmalarda kum, oyun alanları düzenlenirken kullanılması gereken bir malzeme olarak bahsedilirken, dünyadaki çalışmalar kumun eğitici ve tedavi edici boyutu üzerinde durmaktadır. Lowenfeld, Weinrib ve Kalff gibi bilim insanlarının çalışmaları kumun bireyin gelişiminde terapötik ve tedavi edici bir etken olduğunu gösterir niteliktedir (Mayes, Blackwell Mayes ve Williams, 2007). Öte yandan literatürümüzde Türkiye'de kum ile ilgili çalışmaların Cumhuriyet öncesi yıllara dayandığı bilgisi de mevcuttur. Öyle ki orjinali Garcin tarafından kaleme alınan ve 
sonrasında Osmanlıcaya çevirisi yapılan Çocuklara Çamur İşlerini Nasıl Yaptırmalı (Ulvi, 1914) adlı eser toprak ve kumun eğitimde kullanılması ile ilgili ulaşılan kitaplardan en eskisidir. Cumhuriyetin ilk yıllarında eğitimde kumun önemini anlatan diğer çalışmalara örnek olarak Evde Mektep: Oyuncaklar adlı eser (Zekeriya, Halim ve Zekeriya, 1927); Çocuk Nasıl ve Ne İle Oynamalıdır adlı çalışma (Egeli, 1927) ve okullarda kumun kullanılması ile ilgili önermelerin bulunduğu Yeni Mektebin Ders Vasıtalarından Kum adlı kitap (Kültür Bakanlığı, 1934) gösterilebilir.

Eğitimde kumun kullanılması ile ilgili yapılan çalışmalardan birisi de Avrupa'da 1909 yılında yayınlanan; fakat Osmanlıcaya dönemin Maarif Müfettişi Ahmet Hilmi Bey tarafından 1928 yılında çevirisi yapılan Kumlarda Çocuk Oyunları adlı kitabın literatüre kazandırılmasıdır. Bu çalışmanın amacı Türkiye Cumhuriyeti'nin kuruluşunun ilk yıllarında kum havuzlarının önemine dair yapılan çalışmalardan birisi olan ve yabanıı bir dilden Osmanlıcaya çevirisi yapılan Kumlarda Çocuk Oyunları adlı kitabın incelenmesi ve kumun bir eğitim aracı olarak kullanılması üzerine değerlendirmeler yapılmasıdır.

\section{YÖNTEM}

\section{Araştırmanın modeli}

Bu çalışma nitel bir yaklaşımla yapılandırılmıştır. Gözlem, görüşme ve doküman analizi gibi nitel bilgi toplama yötemlerinin kullanıldığı, algıların ve olayların doğal ortamda gerçekçi ve bütüncül bir biçimde ortaya konmasına yönelik nitel bir sürecin izlendiği araştırmalar nitel araştırmalar olarak tanımlanmaktadır. Nitel araştırmalar, toplanan bilgilerden yola çıkarak daha önceden bilinmeyen birtakım sonuçları birbiri ile ilişkisi içerisinde açıklar, sosyal olguları bağlı bulundukları çevre içerisinde araştırmayı ve anlamayı ön planda tutarlar (Yıldırım, 1999). Belirli bir materyalin incelendiği bu çalışmada, nitel araştırma yöntemlerinden doküman analizi yöntemi kullanılmıştır. "Doküman analizi araştırılması hedeflenen olgu ve olaylar hakkında bilgi içeren yazılı materyallerin analizini kapsamakla birlikte geçmiş hakkında bize bilmediğimiz birçok şeyi de sunabilmektedir" (Yıldırım ve Şimşek, 2008, s. 187).

\section{Araştırmanın materyali}

Araştırmanın materyali 1928 yılında dönemin Maarif Müfettişi Ahmet Hilmi Bey tarafından Osmanlıcaya çevirisi yapılan Kumlarda Çocuk Oyunları isimli kitaptır. Yazınsal ve resimli tasvirlerin bir arada bulunduğu kitap toplamda 80 sayfadan oluşmaktadır. İlk basımı Avrupa'da 1909 yılında gerçekleşen kitabın yazarı Danimarkalı eğitimci Hans Dragehjelm'dir.

Hakkında pek fazla kaynak bulunmayan Dragehjelm, 1875-1948 yılları arasında yaşamış ve kum havuzlarını dünyaya tanıtan ilk kişidir. Dragehjelm'in kum ile ilgili çalışmalarının esin kaynağı anaokullarının babası olarak kabul edilen Froebel'dir. Froebel felsefesine göre çocuk, havasız alanlara hapsedilmek yerine açık havada doğal oyunlar oynamalıdır. $\mathrm{Bu}$ felsefeden hareket eden Dragehjelm, 1907 yılında Danimarka'ya kum havuzlarını tanıtmış; kum ile ilgili yapmış olduğu çalışmaların bir derlemesi niteliğinde olan 'Das Spielen der Kinder im Sande' adlı kitabını 1909 yılında yayımlamış ve birlikte çalıştığı Carl Theodor Sørensen ile birlikte 1930'lu yıllarda çocukların gelişim alanlarını destekleyici oyun alanlarının yaratılması üzerine çalışmalar yürütmüştür. Dragehjelm ve Sørensen'in çalışmaları Macera Oyunlarının (Adventure 
Play) da temelini oluşturmuştur (British Adventure Play, 2016; Kunsthalle Zürich, 2016).

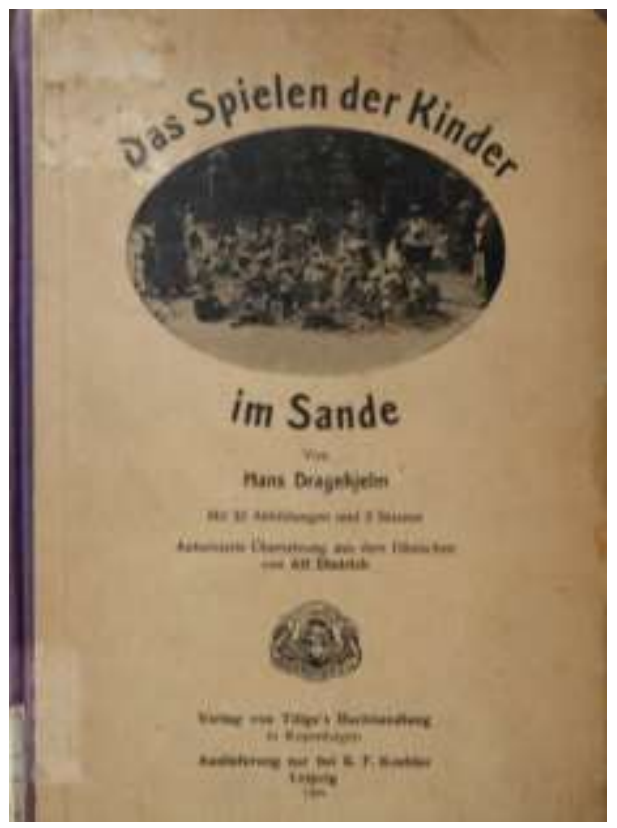

Resim 1. Das Spielen der Kinder im Sande adlı kitabın ön yüzü

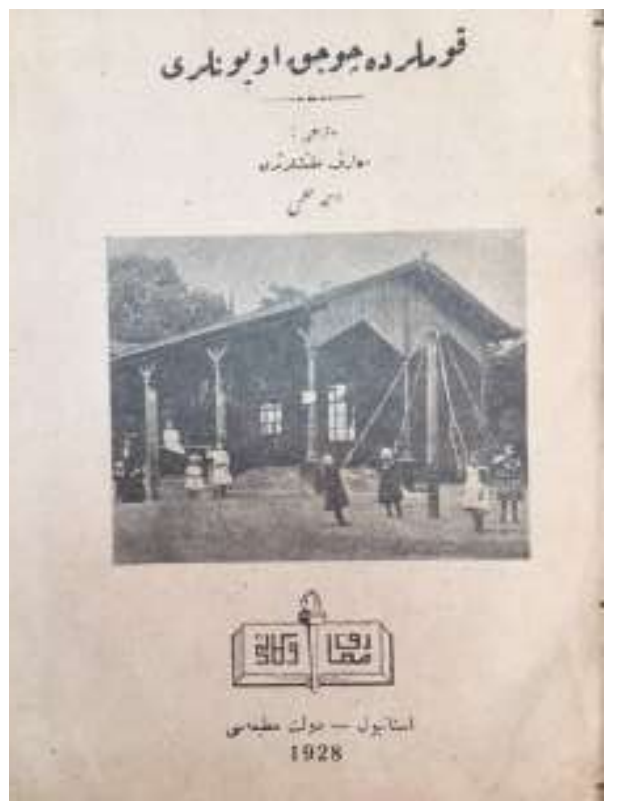

Resim 2. Kumlarda Çocuk Oyunları adlı kitabın ön yüzü 

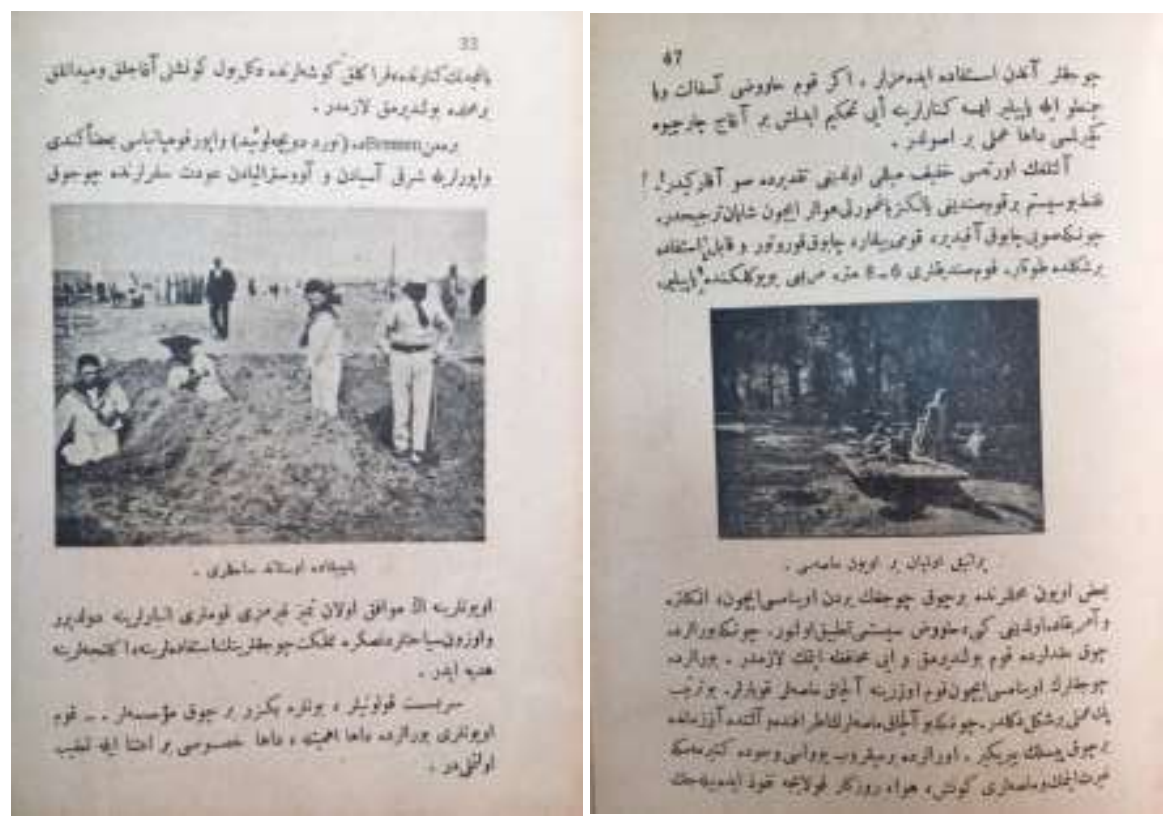

Resim 3. Kitapta yer alan resimli sayfalara örnekler

\section{Verilerin çözümlenmesi}

Araştırma kapsamında incelenen Kumlarda Çocuk Oyunları adlı eser Türkçe dilinde yazılmadığından dolayı veri analizindeki ilk adım eserin çeviri işleminin gerçekleştirilmesi olmuştur. Eserin çevirisi Türkçe ve Osmanlıcaya hâkim iki uzman tarafından yapılmış (Arş. Gör. Ayşegül Akçam ve Yrd. Doç. Dr. Zeki Akçam), yapılan çeviri başka bir uzman tarafından (Prof. Dr. Oğuz Karakartal) görüş alınarak tamamlanmıştır. Doküman inceleme ile toplanan veri, içerik analizi ile çözümlenmiştir. Doküman dikkatli bir şekilde birkaç kez okunduktan sonra kodlar oluşturulmuş, birbiri ile benzer ve ilişkili kodlar biraraya getirilerek belirli temalar altında sınıflandırılmış ve kategorilere ayrılmıştır. Belirli bir kuramdan yola çıkılarak oluşturulabilecek kategoriler olmadığı ve tümdengelimsel bir yaklaşım uygulandığı için, araştırmacı kategorileri analiz sürecinde oluşturmuştur.

Analiz sürecinde oluşturulan kategoriler Çocuğa Bakış, Eğitim Aracı Olarak Kum, Dışarı Oyun Alanlarının Düzenlenmesi ve Farklı Ülkelerde Kum Oyun Alanları olacak şekilde dört başlıkta toplanmıştır. Analiz edilen veri bu başlıklar altında birleştirilmiş ve uzman görüşüne sunulmuştur. Uzmanlar arası \%75'lik bir uyum yakalanmıştır. Son olarak literatür taraması yapılmış ardından raporlaştırma işlemi gerçekleştirilmiştir.

\section{Geçerlik ve güvenirlik}

Nicel araştırmalarda kullanılan geçerlik ve güvenirlik kavramları nitel araştırmalara, bu araştırmaların doğasına uyacak şekilde inandırıcılık (iç geçerlik), aktarılabilirlik (genelleme), tutarlık (iç güvenirlik) ve teyit edilebilirlik (dış güvenirlik) olarak uyarlanmıştır (Lincoln \& Guba, 1985). 
Araştırmacı inandırıcılık ve tutarlığın sağlanması adına çalışmanın her aşamasında nesnel davranmış, veri çözümlemede yer alan aşamalar ve bulgular uzman görüşünden faydalanılarak bu aşamalarda bir fikir birliğine varılmıştır. Doğası gereği genellenemeyen nitel araştırmalar başka çalışmalarla ilişkilendirilebilir ve bu bağlamda aktarılabilirler. Dolayısı ile aktarılabilirlik açısından raporlama süreci boyunca açık ve net olmaya dikkat edilmiş, sayfa numaraları verilerek alıntılar kullanılmış ve çalışma görsel materyallerle desteklenmiştir. Öte yandan bu çalışmanın analizi yapılan materyal ile sınırlı olup, tarihi bir belge niteliğinde olan bir kitabın basıldığı (1909) ve çevirisinin yapıldığı (1928) yıllar kapsamında değerlendirildiği de unutulmamalıdır. Bu süreçte kitaba sadık kalınmış, dolayısı ile kitabın içerisinde geçen yer isimleri ve kişi isimleri de orada geçtiği şekilde aktarılmıştır. Bununla beraber tarihsel bilgi de veren kitaptaki "on yıl öncesi, on yıl sonrası" gibi tabiler değerlendirilirken kitabın orjinal basım yılı olan 1909 senesi dikkate alınmalıdır. Son olarak teyit edilebilirliği sağlamak adına kullanılan materyal diğer araştırmacıların da inceleyebilmesi için muhafaza edilmiştir.

\section{BULGULAR VE TARTIŞMA}

\section{Çocuğa bakış}

Araştırmaya konu olan kitabın incelenen ilk beş sayfasıda Vakit Gazetesi'nin 23 Nisan 1927 Cumartesi günü yayımlanan sayısından alıntılanan bir yazıya yer verildiği görülmektedir. Vakit Gazetesi'nden alıntılanan kısımların Cenap Şehabettin'in Yoksul Çocuklar ve Hakkı Süha'nın Unutmayınız Hudutlar Cesur ve Kuvvetli Çocuklar İster adlı yazılarıdır. Kitabın çeviri işlemini gerçekleştiren Ahmet Hilmi Bey'in bu yazıları kitabın girişine eklemesinin gerçek sebebini bilmek mümkün olmamakla beraber; bu alıntıların dönemin aydın kişilerinin çocuğa bakışı hakkında bilgi verdiği söylenebilir.

Cenap Şehabettin, Yoksul Çocuklar adlı yazısında çocukluk dönemini insanlığın baharına benzetmekte, savunmasız ve sevildiğinin dahi farkında olmayan bebeği masum bir varlık olarak nitelendirmektedir.

"Kaderin yoksul yarattı̆̆ şu çocuğu sevmeyecek miyiz ki insanlığın baharl, gecesi ve sabahıdır... Orada yanan küçük mahluk sevildiğini bilmez; ayakta duracak hali yoktur. Söz namına saçmalar ve hareket namına sallanıyor ve sendeler; mamafih zaylf ve sefaleti üstünde gülen bir yüzü vardır. Çünkü o... çünkü mest-i masumiyettir”' (s. 1).

Yazar, çocukların günahsız varlıklar olduklarından; fakat zaman zaman başkalarının günahlarını çekmek zorunda kaldıklarından bahsetmekedir. Türk çocuğunun dilenci olamayacağını, ona yardım etmenin sadaka değil, bir hayat borcu ve görev olduğunu belirtmektedir. Öte yandan yoksul bir çocuğu kaybetmenin aslında toplumsal bir umudu yitirmekle aynı anlama geldiğini; dolayısı ile bir çocuk öldüğü zaman, bir anne, bir baba veya bir ailenin de yok olacağını savunmaktadır.

Benzer bir şekilde Hakkı Süha da takip eden yazısında çocukların bir milletin geleceği olduğunu belirtmiş, buna ek olarak sağlam vücudu ve sağlam kafası olmayan, yani fiziksel ve bilişsel gelişimi sağlıklı olmayan çocuklar yetiştiren toplumların aslında kendi geleceklerini baltaladıklarını dile getirmiştir.

"Unuttuk ki, çocuk istikbaldir ve çocuğu sağlam vücudlu, să̆lam kafal yetiştirmeyen milletler, istikbale balta ile hücum eden bir mecnunlar kalabalı̆̆ menzilesine iner" (s. 4). 
Hakkı Süha, yazısının devam eden bölümünde çocuklara gereken değeri vermediğimizi, onları güneşin altında, çamurlu ve sıtmalı dere kenarlarında, bakımsız bahçelerde oynamaya mecbur bıraktığımızı; bu nedenle hastalanıp da ölen çocukları aslında toplum olarak cehaletle öldürdüğümüzü; dolayısı ile bu konudaki sorumluluğun da bize ait olduğunu savunmaktadır. Oysaki onlara güneş ve temiz havadan yararlanabilecekleri oyun alanları sunabilirdik.

Giriş kısmında yazıları yer alan her iki yazar da çocuğu geleceğin umudu olarak görmekte ve sağlıklı yetişen çocukların topluma yarar sağlayacaklarını belirtmektedirler. Bir çocuğun sağlıklı yetişebilmesi için de sağlıklı alanlarda yetişmesi ve oynaması gerekliliği üzerinde durulmaktadır.

İlk bölümün takip eden sayfalarında ise bir üniversite profesörü olan Dr. Schmid'in çocuklar hakkındaki görüşlerine yer verilmiştir. Çocukların bir ülkenin geleceği olduğunuzu savunan Schmid, çocuk ölümlerinin oldukça fazla olduğunu ve bu ölümleri azaltmak için birtakım politikalar geliştirilmesi gerektiği üzerinde durmuştur. Öncelikle anne sütünün önemine değinen Schmid, anne eğitimleri organizasyonlarının yapılması, ihtiyaçlı olan çocuklara ücretsiz süt dağıtımı yapılması adına süt damlaları projelerinin hayata geçirilmesi, çocuk muayenelerinin ücretsizleştirilmesi gibi çalışmalarla çocukların temel besin ihtiyaçlarının karşılanması ve böylelikle çocuk ölümlerinin önüne geçilebileceğini önermiştir.

Süt çocukları için bu tür uygulamalar yapılırken okul çağı çocukları için de farklı uygulamalara gerek duyulmaktadır. Schmid, okulların amacının çocuklara oyun imkanı sunmak, bedeni ve aklı eğitmek; bununla beraber muhtaç çocuklara da bu firsatları sağlamak olduğunu belirtmiştir. Süt çocukları ve okul çağı çocukları için bu tür uygulamalar varken 2-7 yaş arasıdaki çocuklara yönelik uygulamaların eksikliğinden söz edilebilir. Schmid'e göre bu yaş grubu çocuklar için yapılan düzenlemeler yetersizdir. Özellikle fakir bölgelerde hijyen sıkıntısı yaşanmakta, hava kirliliği ve evlerin 1 ş1k almaması sağlık açısından sorun teşkil etmektedir. Öte yandan şehirlerdeki evlerin bahçelerinin dar olması, şehir içerisinde tramvay, otobüs ve arabaların trafiği önemli ölçüde meşgul etmesi çocukların oyun oynayabileceği alanları sınırlandırmaktadır. Dolayısı ile çocuklar için temiz ve güneş alan oyun meydanlarına gerek duyulmaktadır. Schmid'e göre bu meydanlar çocukların erişebileceği şekilde düzenlenmeli; işçi ve memurların yoğunlukta çalıştığı yerlerde bu alanlar geliştirilmelidir. Schmid bunun önemli bir ihtiyaç, bir halk, memleket ve gelecek meselesi olduğunu belirtmektedir.

"Şehirlerin avlularl dar evlerinde kafi ziya hava bulunmaz. Sokaklarda tramvaylar, otomobiller o minibüsler arasında çocukları bırakmak tehlikeli olduğu gibi sahi de değildir. Bu gibi sebepler dolaylslyla bu yaştaki çocuklar için bol ziya ve temiz hava yevmi ekmek kadar luzumlu ve ehemmiyetlidir. Bunun için ilk çare olarak çocuklara mahsus temiz ve güneşli oyun meydanları düşünülür. Bu meydanlar şehirlerin bütün mahalleleri tarafindan istifade edebilecek surette tevzi ve taksim olunmalıdır. Ba-husus iş̧i küçük sanatkar, esnaf ve küçük memurların ikamet ettikleri mahallelerde bu meydanları çoğaltmak zaruridir. Çünkü bu bir halk meselesi, bir istikbal meselesi, bir memleket meselesidir" (s. 8).

İlk bölümde yer alan Cenap Şehabettin ve Hakkı Süha'nın yazıları 1920'li yıllarda Türkiye'de; Dr. Schmid'in yazısı ise 1900'lü yılların başında Orta Avrupa'da çocuğa bakış ile ilgili bilgi vermektedir. Her üç yazarın da savunduğu durum çocukların toplumun geleceği, bu yüzden de yatırım yapılması gereken varlıklar oldukları; sağlıklı 
yetişebilmeleri için öncelikle anne sütünden, sağlıklı besinlerden ve temel bakım hizmetlerinden yararlanmaları gerektiği; son olarak da oyunun çocuğun temel hakkı olduğu ve açık havada çocuklara yönlelik oyun alanlarının düzenlenmesi gerektiğidir.

Tanzimat Fermanı'nın ardından Batılılaşmanın etkisi ile gerek yabancı dilden çeviri kitaplar gerekse Osmanlı aydınlarınca yazılan kitaplar eğitim literatürüne kazandırılmıştır. Bu kitaplar arasında yer alan birtakım kitapların, çocuklara olan bakışın şekillenmesine ve değişmesine katk1 koyduğu söylenebilir. Öyle ki Jean Jacques Rousseau'nun Osmanlıcaya çevirisi yapılan Emile adlı eseri ve Osmanlı aydınlarından Ahmet Mithat Efendi, Mehmet Şemseddin ve Ali Nazima gibi yazarların yayınladıkları eserler bunlar arasında sayılabilir. Şüphesiz bu tür eserler çocuklarla ilgili yapılan çalışmalar için de esin kaynağı olmuştur. Özellikle Türkiye Himaye-i Etfal Cemiyeti'nin (Türkiye Çocuk Esirgeme Kurumu) kuruluşu ve cemiyetin çocuklar için yapmış olduğu çalışmalar yadsınamaz. Cemiyet, hem çocukların geleceğin sağlıklı nesilleri olarak yetiştirilmeleri hem de bu bağlamda birtakım haklarının olduğu fikrini yaygınlaştırmıştır. Öyle ki çocukların sağlıklı büyüyebilmeleri ve bebek ölümlerinin azaltılması için çalışan anneler için fabrikalarda anneler mutfağı oluşturulmuş (Baytal, 2009), süt damlaları projesi ile annelerin kimsesiz çocuklara süt anneliği yapmaları, böylelikle çocukların gıdasız kalarak ölmelerinin önüne geçilmeye çalışılmıştır (Ekmekçi, Arda ve Acıduman, 2012). Bununla beraber annelerin bir günlerini çocukla nasıl geçirmeleri gerektiği ve olası ev kazalarını önlemek için çocuğun uyku alanlarının düzenlenmesine yönelik yazılı basında kartpostallara da rastlanmaktadır.

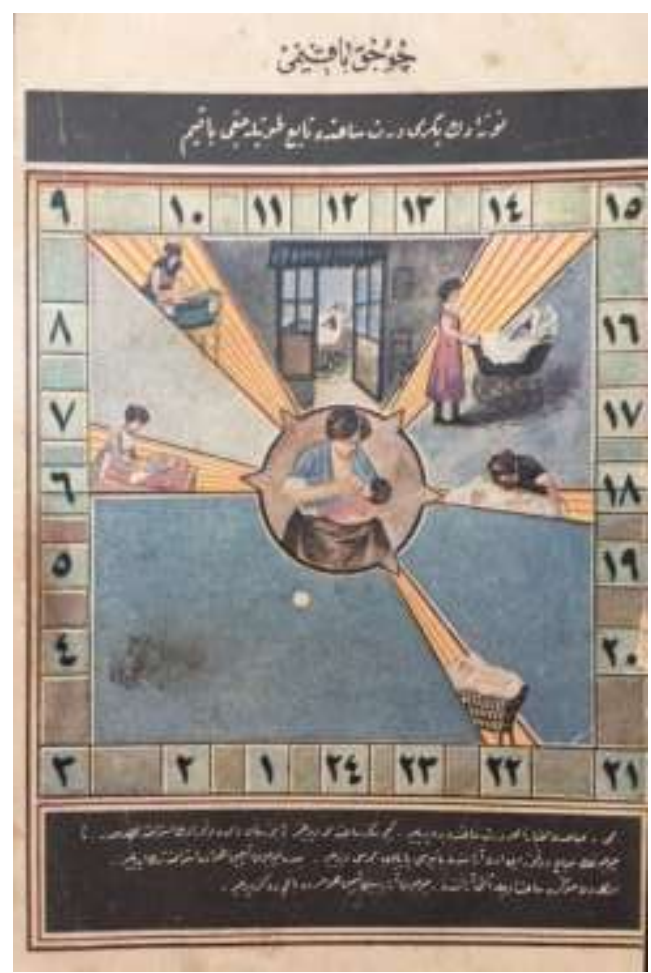

Resim 4. Çocuk Bakımı adlı kartpostal (Türkiye Himaye-i Etfal Cemiyeti, t.y.) 


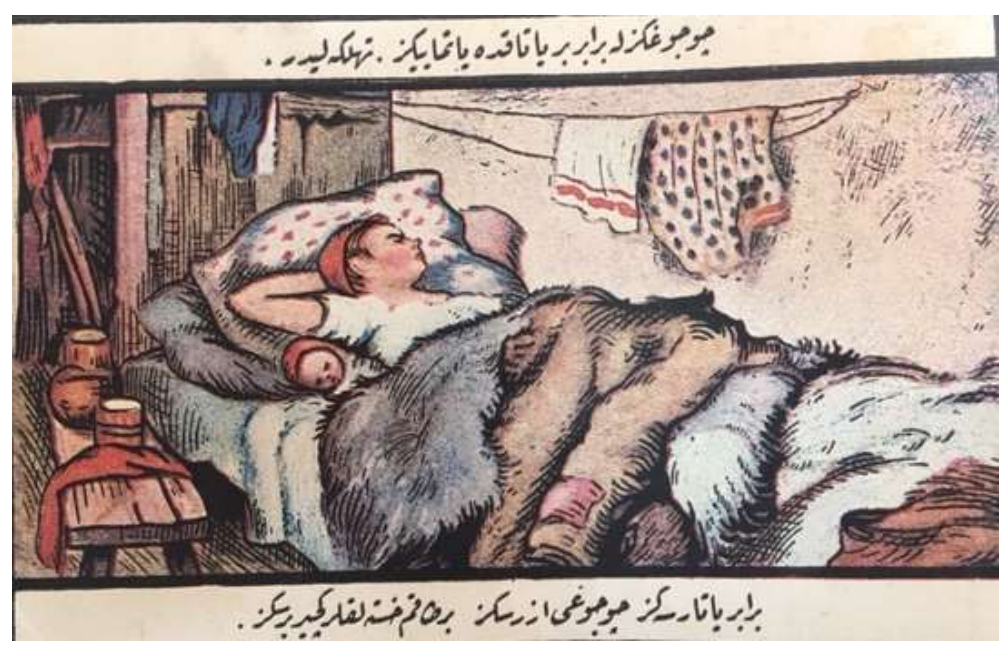

Resim 5. Çocuklarla Beraber Yatakta Yatmayınız, Tehlikelidir başlıklı kartpostal (Türkiye Himaye-i Etfal Cemiyeti, t.y.)

Çocuğa bakışın batılılaşma ile birlikte değişmeye başladığı çalışmalara bir diğer örnek de yine Himaye-i Etfal Cemiyeti'nin 1926 yılında yayımladı̆̆ 1 bir kartpostaldır. Bu kartpostalda temel çocuk haklarından bahsedilmekte, çocuklar anne sütü, temiz gıda, temiz hava, güneş ve oyun oynayabilecekleri çocuk bahçeleri talep etmektedirler (Ummanel, 2017). Bu çalışmalardan yola çıkarak, kitabın yayınlandığı yıllarda çocuğa karşı bakış açısının değişmeye başladığı; onların birer küçük yetişkin olarak değil, farklı ihtiyaçları olan bireyler olarak görüldüğü ve oyun gibi temel haklarının olduğu, dolayısı ile onlara özel oyun alanlarının oluşturulması gerektiği düşüncesinin yaygınlaştırılmaya çalışıldığı söylenebilir.

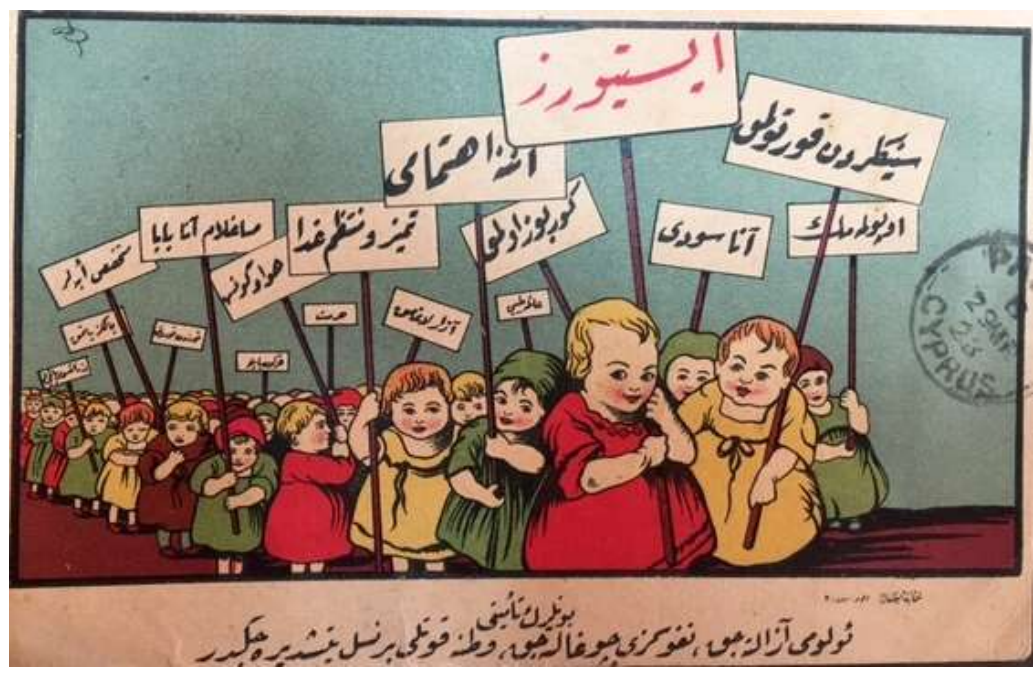

Resim 6. Türkiye Himaye-i Etfal Cemiyeti’nin 1926 yılında yayımladığı bir kartpostal (Ummanel, 2017). 


\section{Eğitim aracı olarak kum}

Araştırma kapsamında incelenen Kumlarda Çocuk Oyunları adlı eserde kum, farklı özellikleri bağlamında değerlendirilmiştir. Kitabın yazarı Hans Dragehjelm kumu, herşeyden önce eğlendirici, çocuğu kendine çeken ve onda oynama arzusu uyandıran keyifli bir oyuncak olarak nitelendirilmiştir. Öyle ki herhangi bir oyuncak çocuğu mutlu edebilirken, kum herhangi bir oyuncaktan farklı olarak değişik şekillere de sokulabilmektedir.

"Çocukları eğlendiren ve hatta kuşların bile midelerinde bulunan kumlardan daha iyi bir oyuncak bilmiyorum" (s. 9).

Ucuz ve sağlıklı bir oyun aracı olan kum, yanında başka materyallerle birlikte çocuğun oyununu destekler. Öyle ki çocuklar kumlarda buldukları taş ve deniz kabuklarını kumla beraber oyunlarında kullanabilmektedirler. Zaman zaman ise hayata dair tecrübelerini kumlar aracılığı ile aktarırlar. Cinsiyete göre oyunların değişebileceğini gözlemleyen Dragehjelm kız çocuklarının daha çok sanatsal oyunları tercih ettiğini, kumlardan pastalar yapıp ev işlerini taklit ettiklerini, erkek çocukların ise taş ve deniz kabularını satarak tüccarlık oynadıklarını, mühendis veya mimar gibi kumda çalıştıklarını belirtmiştir. Öte yandan küçük çocukların daha fazla kumu kazdığı ve eşelediği; büyük çocukların ise kumları birbiri üstüne yı ̆̆dı̆̆ı ve inşaat oyunları tercih ettikleri gözlenmiştir. Zaman zaman hayata dair tecrübelerini de kumlara yansıtan çocuklardan birisinin yakın zamanda kumlara ölmüş kardeşinin mezarını yaptığı ve ona çiçek bıraktığ da gözlenmiştir.

"Bir küçücük kızcağazın mektep tatili esnasında biraderi vefaat etmiş idi. Kardeşinin sevimli hatırası yavrucukta derin izler bırakmış idi. Yalnız başına oturur, kumlardan küçük bir mezar yapar onun üzerine çiçekler diker idi. Bu yavru dört, beş yaşında pek sevimli idi" (s. 20).

Kum oyun alanları çocuklara hem bireysel hem de başka çocuklarla oynama firsatı verir. Dolayısı ile çocuk hem kendi kendine bireysel oyunlar oynayarak becerilerini hem de diğer çocuklarla birlikte oynayarak yardımlaşma gibi sosyal becerilerini geliştirir. Dezavantajlı bölgelerde yaşayan, ihmal edilmiş çocukların iyi bir kum havuzunda daha sevimli ve daha terbiyeli olduğu gözlenmiștir. Bu durum, diğer çocuklarla etkileşimin bu çocuklar üzerindeki etkisini göstermektedir. Bireyin sosyal ortamlarda olumlu sosyal ilişkiler kurmasını sağlayan, başkaları ile iletişimi mümkün kılan, sosyal açıdan kabul edilebilir ve öğrenilmiş davranışlar olarak tanımlanan sosyal becerilerde yetersiz olan çocuklar, yaşamları boyunca kişilerarası ilişkilerde, akademik çalışmalarda, duygusal davranışsal alanlarda ve meslek yaşamlarında çeşitli problemlerle karşılaşabilmektedirler (Durualp ve Aral, 2010).

"Fizyonomisi iyi olmayan fakir mahalleleri ve onların ihmal edilmiş olan caddelerini dolduran yaramaz çocuklar iyi bir kum havuzunda yavaş yavaş daha sevimli daha terbiyeli olmaya çalışırlar" (s. 30).

Kum, çocukların zihinsel gelişimlerini de desteklemektedir. Kum ile oynayan çocuk, eserini oluşturabilmek için dikkatini toplamak ve konsantre olmak zorundadır. Dolayısı ile çocuk öncelikle bu becerilerini geliştirir; bununla beraber kumla oynarken yaptıkları eserleri bozup tekrar üzerinde çalışmaya başladıklarında farkında olmadan sabretme ve bir işi başarı ile sonuçlandırma becerilerini de geliştirmekte, dolayısı ile olumlu 
davranışlar geliştirmeyi öğrenebilmektedirler. Fabes ve arkadaşları (2002) çocukların olumsuz duygularının onların sosyal ilişkilerini etkileyebileceğini savunmaktadırlar. Öyle ki Ummanel (2007) yapmış olduğu bir çalışmada kişisel-sosyal becerilerin akran kabulünü yordadığını saptamıştır.

“Mesela çocuk bir tünel açmak arzusuna mukavemet edemez. Tüneli yapar, yıkılır, bir daha yapar yıkılmak için yeni çareler düşünür. Bulur. Arzularını sabır ile, dikkat ile, taini ile tatbik etmesini ögrenir. Çocuk şüphelerini, hatalarını tekrar ederek izale eder. Binaen aleyh çocukları siyanet ve muhafaza etmek vazifelerini meydana koymak suretle ona alıştırmak için kum kadar iyi bir mürebbiye yoktur" (s. 12).

Kumlarla oynayan çocuk, oyun sırasında yeni fikirler ürettikçe ve uygulamaya koydukça zihinsel becerileri de desteklenmektedir. Çocuk kumdan yaptığ 1 eserde bir hata varsa bunu hemen görebilir ve düzeltme yoluna gidebilir. $\mathrm{Bu}$ sayede kendi kendini güdüleyebilme becerisi de kazanabilmektedir. Sabahattin Ali, 1946 yılında kaleme aldığı Bahtiyar Köpek adlı öyküsünde, kum oynayan çocukları şöyle tasvir etmiştir: ' $Y o l$ kenarındaki küçük parkın kum bahçesinde miniminiler kovaları, kürekleri ile saraylar, nehirler halk eder, sonra bir yumrukta yıkarlar' (Ali, 2016). Öte yandan saldırgan veya kolay sinirlenebilen çocuklar üzerinde kumun sakinleștirici bir etkisi olduğu da belirtilmiștir. Terr'e göre oyun, çocuğun duygusal yüklerini boșalttığı, böylelikle endișe, sıkıntı, üzüntü ve gerginliklerinden kurtulduğu ve bu kaygılarından doğan enerjisini harcadığı bir eylemdir (Köseoğlu, 2000). Bunun yanı sıra oyunun terapötik bir yanının olduğu da belirtilmektedir (Kıran, Çalık ve Esenay, 2013).

"Kumlarda meşguliyet küçüklere büyük bir memnuniyet verir. Onların hassasiyeti üzerinde suret-i mahsusede istirahat ve sukun verici bir tesir yapar ve zaman ile hareketlerinin ve kudretlerinin inkişafi iyi tanzim edilmiş olur. Binaenaleyh kaplıcalı şehirlerde, tedavi ve istirahat şehirlerinde gezme mahallerinde en sihhi tedavi usulleri muayene, bilhassa asabi ve zaylf çocuklar için kumlar ve kum oyun meydanlarl ithal edilmiştir. Bu suretle kum tıbbi tedavi karakterini taşır ve asla zarar vermez. Kumlarda oynayan çocukların yanaklarında taze bir kırmızılık hasıl olur. Gözleri parlar" (s. 34).

Islak, nemli ve kuru kum ile temas eden çocuklar kumla nasıl oynayabileceklerini öğrenir, bunu yaparken de dokunma duyuları gelişir. Öte yandan kumu sıkarken veya şekil verirken farkında olmadan küçük kaslarını da geliştirirler. Dragehjelm çocukların şekiller yaparken her iki ellerini de kullandıklarını, böylece hem sol hem de sağ ellerinin güçlendiğini belirtmiştir. Bununla beraber eserleri üzerinde çalışan çocukların yükseklik, uzaklık gibi algıları da gelişmektedir.

“Çocuk kumlarda bir memur gibi, bir mühendis gibi, bir ressam gibi fikir ve mülâhazasını işine vermiş ve sabr-ı sükunetle çalışır. Bir çocuk birçok günler ev kapısı veya bir tünel, diğer bir çocuk bir bahçe veya gemilerin yuvarlak pencerelerini yapmakla meşgul olur. Her gün birkaç defa aynı şeyleri yapar, bozar, her defasında bir noksanını bulur. Tekrar yapar. Yahud yaparken bir noksanı yüzünden yaptığı şey bozulur, yıkılır. Gayr-ı iradi olarak hakimi ve riyazı kaidelere uyar. Yavaş yavaş boy, uzaklık, yüksekliğini ve elindeki kumların halini, şeklini ögrenir" (s. 16-18).

Çocuklar kumu farklı bir nesneymiş gibi düşünebilir veya onunla çeşitli şekiller yapabilirler. $\mathrm{Bu}$ oyunlar sirasında kendi kendilerine hikayeler uydurup o hikayelere uygun şekiller, yapılar geliştirebilirler. Çünkü kumlar çocuklar için canlı hikayelerle doludur. Çocuklar kumlar aracılığı ile hikayeler uydurup her defasında başka bir role 
bürünebilirler. Gerek yaratıcılıklarının gerekse hayal güçlerinin desteklendiği kum oyunlarında rol model aldıkları kişileri taklit edip gelecekteki uğraşlarının bir provasını yapabilirler. Pulaski (1970), çalışmalarında minimal düzeyde yapılandırılmış bir materyalin yapılandırılmış bir oyuncağa göre çocuklar arasında daha fazla hayali oyun aracı olarak seçildiğini ve tercih edildiğini gözlemlemiştir. İşte kum da bu tür bir malzemedir.

“Onlar çok defa bir sanaatkar gibi kumlarda kendi eserleri üzerinde çalışırlar. Yaptıkları resimler şekillerle fikirlerinin doğru veya yanlışlıklarını ortaya koyarlar. Bunlar tashih edilir. Her tashih edilen şekiller, resimler çocuklara yeni yeni fikirler verir. Çocuk bir kere kumlar içinde şekillerini yapmaya başladı mı artık evini diker birşey alakadar etmez. Derin bir haz ile sessiz, sakin işine devam eder ve eserini meydana çıkarır" (s. 11).

Ayaydın (2011) oyun oynayan her çocuğun kendisine hayali bir dünya yarattığını ve o dünyayı kendisini mutlu edecek şekilde yeniden düzenlediğini savunmaktadır. Aral, Gürsoy ve Köksal (2001) oyunun çocuğun yaşadığı dünya ile yaşamak istediği hayal dünyası arasında bir köprü vazifesi gördüğünü, onun yaratıcılığının ortaya çıkmasında bir araç olduğunu ve oyun yolu ile yaratıcı düşüncelerini ortaya koyarak dış çevreyi tanıyabildiğini belirtmişlerdir.

Kum ile oynayan çocuk oyun sırasında yaşadığg problemlerle başa çıkabilmek için farklı çözüm yolları üretmek zorunda kalabilmektedir. Bu durum çocuğun problem çözme becerilerini de geliştirir. Bingham, bir amaca ulaşmakta karşılaşılan güçlükleri aşma süreci olarak tanımladığı problem çözme becerisini, öğrenilmesi, elde edilmesi ve sürekli olarak geliştirilmesi gereken bir yetenek olarak görmektedir. Zaman, çaba, enerji, alıştırma ve yardım gerektiren bir süreç olan problem çözme, yaratıcı düşünce, zeka ve duyguları içerisinde barındırmaktadır (Özdil, 2008). Dolayısı ile problem durumlarla karşılaşan çocuğun bu becerileri gelişecek ve zihinsel gelişimi desteklenecektir. Dragehjelm tüm bunlara dayanarak kumun öğretici bir yanı olduğunu, çocuğa yeni beceriler kazandırırken bir rehber konumunda olduğunu, kumla oynayan çocuğun beden sağlığının yerinde olduğunu, kemiklerinin güçlendiğini, el becerisi kazandığını ve kumun çocuklar için sağlıklı bir materyal olduğunu belirtmiştir.

“Kum oyunlarl, kum meydanları birer kuvvet ve kudret mektebidir. Küçükleri tedricen büyük oyun ve spor mahallerine hazırlar ve arkadaşlarlyla dostane yaşamasını birlikte çalışmasını öğretir" (s. 37).

Araştırma kapsamında incelenen Kumlarda Çocuk Oyunları adlı kitaba dayanarak kumun bir eğitim aracı olarak kullanılabileceği ve çocukların zihinsel, bedensel, ve sosyal becerilerini destekleyen bir materyal olduğunu söylenebilir. Öyle ki Türkiye'de 1934 yılında Kültür Bakanlığı tarafından basılan Yeni Mektebin Ders Vasıtalarından Kum adlı kitapçıkta da kumun bir ders aracı olarak kullanılması önerilmiştir (Kültür Bakanlığı, 1934). Küçük yaşlarda sosyal becerilerin kazanılmasının yaşamın ilerleyen yıllarına etkisi büyük olacaktır. Zira erken çocukluk döneminde kazanılmayan ve geliştirilmeyen birtakım becerilerin ilerleyen yıllarda kazanılması güç olacağı gibi bireyin toplumda kendine bir yer edinebilmesini ve toplumda diğer insanlarla uyum içerisinde yaşayabilmesini de zorlaştıracaktır. 


\section{Dışarı oyun alanlarının düzenlenmesi}

Denize veya nehirlere yakın yerlerde yaşayan ya da yaz tatillerinde buralara gelme olanağı olan çocuklar kumlarla diğer çocuklara kıyasla doğal olarak daha erken tanışmakta ve daha fazla meşgul olmaktadırlar. Fakat diğer çocuklar kadar şansı olmayan ve yaz tatillerini evlerinde geçirmek zorunda kalan çocukların da sayısı fazladır. Büyük şehirlerde, apartmanlarda yaşayan çocuklar için kum oyun alanları, parklar ve bahçeler onların temiz hava almaları, güneşten faydalanmaları ve hareket ihtiyaçlarını gidermeleri için uygun alanlardır. Nitekim Türkiye Çocuk Esirgeme Kurumu'nun 1926 yılında yayımladığı bir kartpostalda da çocukların hava, güneş ve kendilerine özel bahçelere ihtiyaç duydukları üzerinde durulmuştur (Ummanel, 2017). Çocuklara en üst düzeyde yararlı olabilmesi için bu alanların dikkatlice düzenlenmesi gerekmektedir. Öyle ki Umut Vakfı (2003), yayınlamış oldukları bir raporda çocukların temel haklarından birisinin de oyun olduğunu belirterek her çocuğun bu hakkını yerine getirebilmesi için kentin her alanını rahatlıkla kullanabilmesi gerektiği; bu alanların güvenli ve erişebilir olması ve yeni şeyler yaratmaya, var olanı değiştirmeye elverişli olmasının önemi üzerinde durmuştur.

Geniş alanlarda, genel kullanım alanlarında, mahallelerde, park ve bahçelerde kum oyun alanlarına da yer verilmelidir. Dragehjelm'e göre bu tür alanlarda çocuklara bir meşguliyet sunulmazsa, çocuklar meşgul olmak için çevrelerindeki bitkilere, çiçeklere zarar verebilirler. Dolayısı ile bütün park ve bahçelerde çocukların meşgul olabileceği kum oyun alanları yaratılmalıdır. Çocuklar buralarda temiz hava ihtiyaçlarını da giderebilmektedirler.

"Bütün park idareleri çocukların oynamasına çalı̧masına mahsus küçük meydanlar bulunmasına dikkat ederler. Bu yalnız çocukların hakkı değil aynı zamanda park idarelerinin menfaati için yapılmış çok emelli bir tedbirdir. Aksi takdirde derelere ve çiçeklere zarar gelir" (s. 25).

"Ĕger küçüklere bahçelerde oyun mahalleri verilmez ve ağızlarının tadı kaçırllır ise onlar da büyüklere müşkilat çıkarırlar. Nerelerde halkın sihhati düşünülür, onların sihhati bir surette temiz hava almaları, tenzih etmeleri temin edilir ise oralarda çocukları da düsünmemek kabul değildir. Onun içindir $k i$ bu gibi mahallerde yavruların oynamaları, eğlenmeleri için mahalleler, meydanlar, kum havuzları tertib ve tanzim etmek pek zaruri olur" (s. 26-27).

Kum oyun alanlarının temiz alanlarda olmasına dikkat edilmeli; çocukların sert rüzgardan korunabilmeleri için kuru ve ağaçsız yerlerde bu alanların yer alması engellenmelidir. Rüzgar alan yerlerde çocuklar terleyip hastalanabilmektedirler. Öte yandan çok kalabalık ve çok hareketli alanlardan da uzakta olmalı; fakat sokaktan geçenler tarafından da rahatça görülebilen yerlerde olmalıdır. Burada amaç çocukları caddenin tehlikelerine karşı korumaktır. Kum oyun alanlarının mümkün olduğunca toplu yerleşim yerlerine de yakın olması gerekmektedir ki çocuklar buralara rahatça ulaşabilsinler. Öyle ki cemiyet bahçeleri, ağaçlık yerler, hayvanat bahçeleri, çocuk yuvaları, parklar ve anaokullarda da kum oyun alanları bulunmalıdır. Dragehjelm, yaz tatillerinde okul bahçelerindeki kum havuzlarında oynayan çocukların okula karşı olumlu bir tutum geliştireceğini ve okuldan kopmak istemeyeceğini iddia etmiştir. Fakat kum alanları kenar ve karanlık köşelerde değil güneş alan açıklık yerlerde olmalıdır. Böylece soğuk havalarda kapı araları ve merdiven sahanlıklarında oynayan çocuklar temiz hava ve güneşten faydalanabileceklerdir. Nitekim aile ve belediyelerin görevleri arasında 
çocuklara sağlıklı oyun alanları oluş̧urmak da vardır. Birleşmiş Milletler'in 20 Kasım 1989 tarihinde, Türkiye'nin ise 1990 yılında kabul ettiği Çocuk Hakları Sözleşmesi'nin 31. maddesine göre çocukların boş zaman geçirmeye, dinlenmeye, yaşlarına uygun olarak oyun oynamaya ve kültürel ve sanatsal etkinliklere katılmaya hakları olduğu vurgulanmaktadır (UNICEF, 2016). Dolayısı ile toplum ve kamusal otoriteler bu hakk1 yerine getirmeye çalışmalıdır. Bu konuda topluma ve yerel yönetimlere büyük görevler düşmektedir. Çakırer Özservet'e göre (2015b) belediyeler sınırları içerisinde yaşayan vatandaşların ve çevrenin ihtiyaçlarını en iyi bilen kurumlardır. Çocukların, belediyelerin sorumluluk alanlarında nüfusun önemli bir dilimini oluşturduğunu düşünürsek dışarı oyun alanlarının düzenlenmesi konusunda belediyelere büyük ve önemli görevler düştüğü söylenebilir.

"Ailelerin ve belediyelerin vazifeleri çocuklara oynamak için her türlü şeraite riayet edilerek ihzar olunmus oyun mahalleri lazımdır. Bu mahaller yapılmaz ise çocuklar bilmecburiye sokaklara dökülürler. Topraklarla oynarlar. Elbiselerini kirletirler ve sokağın her türlü zararın görürler. Bilhassa kayda şayandır ki toprakların arasinda kesretle bulunan solucan yumurtaları çocukların tırnaklarl arasina dolar ve o suretle maddelerine, bağırsaklarına geçer" (s. 40-41).

Tüm bunların yanı sıra apartman avluları ve müstakil evlerin bahçelerine de kum oyun alanları yaptırılmalıdır ki, çocuklar kumdan faydalanabilsinler.

"Yerlerde birakmak, hareketsizliğe mahkum etmek, yahud kirli pis sokaklarda oynamalarina meydan vermek, yahud caddelerin bir türlü tehlikelerine maruz bulundurmak çocuğun sihhatine ve hayatına karşı cinayet işlemek demektir. Eğer ikametgahlarını civarında kum oyun mahalleri var ise müşkilat kısmen izole edilmiş demektir. Bunun için ev sahipleri ve kiracılar müsstereken ve mütekabilen apartmanların avlularında, hususi ikametgâhlarının bahçelerinde birer küçük oyun mahalli kum havuzu vücuda getirmeye çalı̧̧malıdır" (s. 36).

Oyun alanlarındaki kumlar yığın şeklinde olmamalıdır. Yığın halinde kum tepeleri oluşturulursa büyük çocuklar bu tepelerin üzerinden kaymaya çalışabilir ve tehlikeli durumlar ortaya çıkabilir. Dolayısı ile kum oyun alanlarındaki kumların tahta kenarlıklarla çevrilmiş bir sandıkta olması veya havuz şeklinde düzenlenmesi gerekmektedir.

"Kum oyun meydanlarının tesisi için muvaffak sistemler bulmak lazımdır. Bunlar başlıca yığın şeklinde, tahta kenarlıklarla çevrilmiş sandlk şeklinde, yahud büyük havuz şeklinde olur. Bu üçşekilden hangisi hangi mahalle tevafuk ederse o şekilde tesis edilmelidir. Oyun esnasinda kumu topluca bir halde bulundurmak istifadeyi mucib olur. Eğer kuma kafi derecededir yenilir verilir ise birçok çocuklar üzerinde rahatça oynarlar. Bunun için tahta kenarlikl kum havuzlarl tercih olunur" (s. 44).

Kumları çevreleyen tahta kenarlıkların alçak olması gerekir ki çocuklar istediklerinde buralara oturabilsin ve o şekilde çalışabilsinler. Kenarlıklar yüksek olursa çocuklar rahat edemezler. Öte yandan kumların içerisinde muhafaza edileceği sandıkların da üç, dört, beş, altı, yedi veya sekiz köşeli olması, kapladığı alanın da altı veya sekiz metre kare olması önerilmektedir. Kum sandıkları sağlam olmalı, içerisine çamur karışması engellenmelidir. İçerisine çamur karışan kum çocuklar için zararlı olabilmektedir. Kum ile toprağın karışmaması için kum sandıklarının veya kum havuzlarının altının çimento olması, kenarlıkların tahtadan ve alt kismın da ortadan hafif meyilli olması 
gerekmektedir. Böylece yağmurlu havalarda su sandıkta birikmez, kumu yıkayıp temizledikten sonra kolayca akar ve havuzdan boşalır. Bu sırada kum da havuzda muhafaza edilir ve azalmaz. Dragehjelm yağmurlu ülkelerde bu sistemin uygulanmasını önermektedir. Kumu fazla yağmur, güneş ve sıcaktan korumak için üzerinin örtülmesinde de fayda vardır. Ağaçlık bölgelerde ağaçlar bu işi görürken, çok fazla ağacın olmadığ bölgelerde kum sandıklarının veya havuzlarının örtülmesi gerekebilmektedir. Dragehjelm, başıboş dolaşan köpeklerin ve yere tüküren insanların kumlar için tehlike olduğunu belirtmiştir. Dolayısı ile köpeklerin başıboş dolaşmaması ve insanların daha duyarlı olması konusunda önermeleri bulunmaktadır. Kum havuzlarının üzeri kapatılabileceği gibi gerekirse kum meydanlarının etrafının da kapatılabileceğini belirtmiştir.

“Kum havuzlarının üzerlerinin örtülmesi çok güneşli, çok sıcak, çok yağmurlu şehirlerde, memleketlerde bir ihtiyaçtır. Bu gibi mahallerde kum havuzlarının üzerlerine yelken bezinden gibi bir şemsiye açılır. Örtüler yapmak ve bu örtüleri güneş ve yağmur geçtikten sonra bir tarafa çekmek ve toplamak çok muaffakdır" (s. 49).

Çocuklar kumun üzerinde uzun saatler geçirebilirler. Ne yazık ki uzun süre kumun üzerinde oturmak soğuk almalarına neden olabilir. Bu yüzden kumların üzerinde kum masaları veya oturma kanepeleri bulundurulmalıdır. Gözlenen bazı bölgelerde kum havuzlarının yanına yorulan, güneşten veya yağmurdan kaçan çocuklar için kapalı oturma alanlarının yapıldığı belirtilmiştir. Bu durum, bu bölgelerde çocuğa verilen değeri de göstermektedir. Araştırmacılar, sanayileşme ile birlikte kent yaşamının yaygınlaştı̆̆ını ve kentlerdeki nüfus artışının çocuk oyun alanlarını kısıtlamaya başladığını belirtmektedirler. Bu durum gelişmekte olan ülkelerde çocukların sokak ile bağlarının yavaş yavaş kopmaya başlamasına neden olmuştur. Bazı ülkeler bu konuda önlemler almaya başlamış; 1935 yılında Stockholm'ün gerekli noktalarına çocuk oyun alanlarının yapılması planlanmış, Amerika'da San Fransisco sokaklarına çocukları tehlikelerden korumak için hız sınırlandırılması getirilmiş, bazı sokaklar trafiğe kapatılmış ve ağaçlandırma çalışmaları ile birlikte yeni oyun alanları kurulmuştur (Tanon, 1978; Ergun, 2000, Öztürk, 2015).

Kum oyun alanlarındaki kumların çocuklara zarar vermemesi açısından temiz ve yıkanmış olması gerekmektedir. İnce kum kullanılırsa rüzgarlı havalarda uçacak, ayrıca nefes alamadığı için kumlar birbirine yapışacaktır. Öte yandan kumun toprakla karışmaması gerektiği; aksi halde yağmurlu havalarda çamura, rüzgarlı havalarda ise toza dönüşebileceği belirtilmiştir. Dolayısı ile kumun sandıktaki tek materyal olması ve temizlik açısından sık sık değiştirilmesi gerekmektedir.

"Eğer kum ince ve çamurlu olur ise o zaman birçok mahzurlar hususuyla hastalık sirayeti tehlikesi vardır. Kumlar üzerinde birçok çocuklar toplanırlar. Otururlar, parmaklarını ağılarına, burunlarına sokarlar ve ellerini yıkamadan ekmek, pasta yemek gibi taklidler yaparlar. Bu gibi hallerde sirayet tehlikesi çoğalır ve kolaylaşır. Fakat böyle bir sarı hastalı zuhur etse bile o gene geçilemeyeceğini iddia edilemez" (s. 55-56).

Kumlar, yuvarlak taneli olmalı, çocuklara zarar vermemesi için keskin ve sivri maddelerden arındırılmalıdır. Çocukların oynamaları için en uygun kum deniz kumudur. Fakat tuzlu ve nemli olan deniz kumunun öncelikle bir havuzda köpürünceye kadar su ile karıştırılıp temizlenmesi ve fazla tuz ile nemden arındırılması gerekmektedir. Kumun nemli olmaması önerilirken, çok sıcak yaz günlerinde kumları ara sıra sulamanın iyi 
olacağ da belirtilmektedir. Bu şekilde hazırlanan kumun iyi muhafaza edilmesi oyun meydanlarının kusursuz düzenlenmesi ile mümkündür.

Son olarak Dragehjelm, kumların çocuklar için gerekli olduğunu ve halkı bu konuda bilgilendirmek gerektiğini; kum oyun alanlarının artırılmasını; kumun bedeni ve ruhu beslediğini, çocuğu sosyalleştirdiği; belediyelerin çocukların kazmaları, koşmaları, oynamaları ve eğlenmelerine yönelik korunaklı alanlar tahsis etmelerini belirtmiştir. Geleceğimiz olan çocukların beden eğitimleri ancak bu alanlarla mümkündür. Bu yüzden dışarı oyun alanlarına önem verilmelidir.

"Düşünmelidir ki bugünkü cemiyet yarınki neslini sokaklarda, tozlar, çamurlar arasında her türlü hayati tehlikelere maruz bırakarak ahlaksız, sükut, cllız bir halde yetişmesini asla arzu etmez. Her ferd tiyatrosundan, sözünden, husn edilmeyecek kadar cüzü bir miktarı bu çok ehemmiyetli maksat için verecek olur ise - ki bugünkü yavrular buna muhtaçtır - maksat hasıl olur. Bu hususta bunun için yüksek masraflara da ihtiyaç yoktur. Ali-yi hale terk edilmiş mahallerden istifade edilebilir. Biraz kum, biraz temizlik ve ucuz bir tesisat" (s. 64).

\section{Farklı ülkelerde kum oyun alanları}

Orjinalini Danimarkalı eğitimci Hans Dragehjelm'in yazdığı, 1928 yılında Maarif Müfettişi Ahmet Hilmi Bey tarafindan Osmanlıcaya çevirisi yapılan Kumlarda Çocuk Oyunları adlı kitabın son bölümünde farklı ülkelerdeki kum oyun alanlarına örnekler verilmiş, bu ülkelerde oyun alanlarının düzenlenmesi ile ilgili yapılan çalışmalar derlenmiştir. Bu ülkeler arasında Almanya'ya emsal teşkil ettiği için ayrıca değinilmiş ve Almanya'daki farklı şehirlerden de örnekler verilmiştir.

\section{Almanya}

1890 yilında Alman İmparatoru ve Prusya Kralı Kaiser II. Wilhelm, Berlin'de düzenlenen eğitim kongresinde "Biz kutlu bir nesile sahip olmak istiyoruz" demiş, büyük yankı uyandıran bu sözler üzerine gençlerin oyun ve spor ile yetişebilmesi için ülke genelinde çalışmalara başlanmıştır. Milletvekilleri ve profesörlerin gerçekleştirdikleri ortak çalışmalar sonucunda bir rapor hazırlanmış ve dokuz soruluk bir form ülke genelindeki belediyelere gönderilmiştir. Gönderilen form aşağıdaki soruları içermektedir:

1- Küçük çocuklara özel oyun meydanları var mı?

2- Bu meydanlarda kum alanları var mı?

3- Bu alanlar ne kadar büyüklüktedir, şekilleri nasıldır?

4- Kum alanları içerisinde asfalttan yapılmış olanları var mı?

5- Kum oyun alanlarına yönelik özel bir düzenleme var mı? Örneğin;

6- Çocuklar el arabalarıyla kumları bir yerden başka bir yere taşıyor mu?

7- Kum masaları var $\mathrm{m} ı$ ve çocuklar üzerlerinde oynuyor mu?

8- Kum oyun alanlarının üzerleri örtülmüş mü?

9- Çocukların oyunlarına aileler ilgi gösteriyor mu?

10- Otel bahçeleri gibi yerlerde kum oyun alanları var mı?

11- Ne zamandan beridir bu tür oyun alanları düzenleniyor?

12- Bu düzenlemeler yapılırken sağlıkla ilgili durumlar dikkate alınıyor mu? 
Çalışma kapsamında gönderilen sorulara ülke genelinde 173 belediyeden cevap alınmıştır. Bunlardan 16'sı küçük çocuklar için böyle meydanların olmadığını bildirmiş, geriye kalan cevaplara bakıldığında ise olumlu cevap alınan yerlerde kum oyun alanlarının toplamda 100,000 metrekarelik bir alana yayıldığı anlaşılmaktadır. Özellikle Breslav, Kasel, Geminç, Dortmiştad, Dresden, Frankfurd, Hamburg, Hanover, Münih ve Çivikar belediyelerinin bu çalışmaya büyük ilgi gösterdikleri belirtilmiştir.

Fikrin kime ait olduğu bilinmemekle beraber Hamburg'taki ilk kum havuzunun 19. yüzyılın sonuna doğru yapıldığı kayıtlarda mevcuttur. Hamburg belediyesi şehir genelinde toplamda 83 adet kum havuzu olduğunu ve bu havuzların büyüklüklerinin beş ile 50 metrekare arasında olduğu, aralarında 600 metrekarelik bir de kum oyun alanının bulunduğu bilgisini vermiştir. Bu havuzların bazılarının altı düzgün bir şekilde çimento ile kaplanmıştır. Hamburg'taki kum havuzlarına getirilen kumların kaynağı Elbe nehridir. Temiz olan kumlar ince taneli değildir, bu yüzden toz yapmamaktadır. Öte yandan kumlar sürekli değiş̧irildiği için hastalık şikayeti de yoktur. Hamburg’ta kum havuzları düzenli olarak yenilenmekte ve sayıları da artmaktadır. Elbe nehrinin kıyısında 80-100 metrekare büyüklüğünde çocuklar için bir oyun meydanı bulunmaktadır. Bu oyun meydanının idaresi Kohlbrand Oyun Meydanı Cemiyeti (Verein Kohlbrand Spielplatz) tarafından yapılmaktadır. Cemiyetin 1908 yılındaki raporuna göre oyun meydanını 15 Nisan'dan yıl sonuna kadar toplam 279,289 çocuk ziyaret etmiştir. Hamburg belediyesi çocukların her firsatta anneleri ile buraya geldiklerini ve günün birkaç saatini burada geçirdiklerini belirtmiştir.

Dresden belediyesi verdiği raporda sınırları dahilinde 48 oyun alanı ve 72 kum havuzu olduğunu bildirmiştir. Kum havuzlarının önceleri tahtadan yapıldığını, bu nedenle kumların kolayca dağıldığını; fakat daha sonra bu durumu düzelttiklerini belirtmişlerdir. Dresden'deki kum sandıkları altı metre uzunluğunda ve dört buçuk metre genişliğinde olup sekiz köşelidir. Derinliği $40 \mathrm{~cm}$, yerden yüksekliği ise $10 \mathrm{~cm}$ 'dir. Sandıklar hazırlandıktan sonra çimento ile sıvanıp sabitlenmektedir. Bununla beraber her oyun alanına sıralar dizilmekte ve çocukların masa gibi bu sıraları kullanması sağlanmaktadır.

Dresden'den farklı olarak Münih’te kum havuzları ağaç çerçeve ile çevrelenmiş; fakat henüz çimento kullanımına başlanmamışıı. Temiz ve yıkanmış nehir kumu kullanılan havuzlar rüzgar almayan, ağaçlık alanlara yapılmıştır. Şehir genelinde 32 oyun alanı bulunmakla beraber bunlardan 21 tanesi okul bahçelerinde yer almaktadır. Sadece on oyun alanında ve şehrin bazı semtlerinde küçük çocuklar için kum parkları bulunmaktadır.

Hanover'de çocuklara özel 14 oyun alanı bulunmakta, bu alanlarda toplamda 15 kum yığını yer almaktadır. Yığınlardan altısı ağaç çerçeveli ve altı köşeli sandıklarla çevrili olmakla beraber daha çok sarı kumun kullanıldığı belirtilmiştir. Hanover'de kum oyun havuzlarının eğitim aracı olarak kullanılması yönündeki görüşlerin çeşitli olduğu, karşıt görüşlerin de bulunduğu yetkililer tarafından belirtilmiştir.

Leipzig'den alınan bilgiye göre bu şehirde öğretmenler birliği başkanının çocuklara doğayı sevdirmek için tatil seyahatleri düzenlediği; bu seyahatlerde çocukların kum ve çamur oyunları oynadıkları belirtilmiştir. Bu oyunların belli bir sisteme bağlı olmadığı, çocukların kum ve çamur ile oynamalarının doğal bir şekilde geliştiği söylenmiştir. Büyük yaşlardaki çocukların kumu harita yapmak için kullandıkları belirtilmiştir. 
Berlin'de ise özel bir uygulama olmamakla beraber her yıl yaz tatillerinde okulların oyun alanlarının çocuklara açıldığı, bu alanlara iki araba kum döküldüğü ve kadınların idaresinde çocukların buralarda oynadıkları belirtilmiştir.

Çivikar belediyesi şehrin her yerinde oyun meydanlarının olduğunu, 1600 metrekare, 2800 metrekare ve 27000 metrekare olmak üzere üç tanesinin çok büyük olduğunu ve her birinde bir veya iki adet kum havuzu olduğunu belirtmiştir. Zaman zaman okul bahçelerinin de çocukların oynamasına açıldığ 1 ve şehre yakın bir ormanda da oyun alanlarının var olduğu ayrıca bildirilmiştir. Benzer bir şekilde Geminç'te 80-800 metrekare arasında 25 oyun alanı ve her bir oyun alanında dört metrekare kum havuzu bulunmaktadır. Kum havuzlarının bir kısmında ağaç kütüğü üzerine masalar, bazılarında ise tahteravalliler bulunmaktadır.

Son olarak Bremen'de oyun alanlarının bulunduğu; Wilmersdorf'ta zarif bir oyun alanının olduğu; Hella, Düseldorf, Frankfurt ve Mayn'da üzeri örtülmüş kum alanlarının olduğu verilen bilgiler arasındadır.

\section{Avusturya}

Viyana'da kumla oynayan çocukların sayısı günden güne artmaktadır. Kumlar nehir kıyılarından getirtilmekte ve kum sandıklarında muhafaza edilmektedir. Genellikle öğleden sonraları çocuklar aileleleri ile birlikte buralara gelmekte ve kumla oynamaktadırlar. Kum oyun alanlarının yanı sıra okul bahçelerinde de kum havuzları bulunmaktadır, fakat bunların sayıları azdır.

\section{Macaristan}

Budapeşte'de kum oyun alanları önceden beri çocuk ve ailelerin hoşuna gitmektedir. Ancak oyun alanlarında kum havuzlarının sayısı oldukça azdır. Var olan havuzların etrafı tahta kenarlıklarla çevrelenmiş olup karşılıklı iki kenarı açıktır. Çocuklar kürek ve el arabaları ile bu havuzlarda oynayabilmektedirler. Kum oyun alanlarına ilkokullarda pek fazla yer verilmemiştir; ancak anaokullarında bu alanlar mevcuttur.

\section{İsviçre}

Zürih'te her okulun büyük bir oyun bahçesi bulunmaktadır. Bu bahçeler kumlu bir çakıl ile kaplanmış, kısmen de çimlendirilmiştir. Şehirde ince ve güzel kum olmadığ 1 için çocuklar ince taneli çakıllarla oynamaktadır. Bazı anaokullarında kum havuzları bazılarında da renkli kum sandıkları olmasına rağmen kumun eğitimde büyük rol oynadığı düşünülmemektedir.

\section{Hollanda}

Amsterdam'daki okullarda kum havuzlarının varlığ $20-25$ sene öncesine dayanmaktadır. Küçük sınıflar teneffüs saatlerinde kum havuzlarında oynamaktadırlar. Kum sandıkları ortalama 12 metrekare olup nadiren daha büyükleri de vardır. Bu sandıklar okul bahçesinin bir köşesinde yer almakta ve yılda bir kez temizlenmektedir.

\footnotetext{
* Hans Dragehjelm, Kumlarda Çocuk Oyunları adlı kitabın orijinalini 1909 yılında yazmıştır. Dolayısı ile Amsterdam'daki kum havuzlarının varlığı 1880'li yıllara dayanmaktadır.
} 


\section{Belçika}

Brüksel'de ilk kum havuzu 1908 yılında oluşturulmuştur. Bu zamana kadar ülkede kum havuzu bulunmamaktaydı. Yeni açılan havuzların üzerleri çocukları yağmur ve güneşten korumak için hasır ile örtülmüştür.

\section{Danimarka}

Dragehjelm, son zamanlarda Danimarka'da beden eğitimine daha fazla önem verilmeye başlandığını belirtmiştir. Ülkede kum havuzları yaygın olmakla beraber bir taraftan eskiyenler tamir edilmekte diğer taraftan da yeni havuzlar yapılmaktadır. Danimarka, Almanya gibi bu alanda diğer ülkelere göre daha ileridedir.

Rusya

Kum havuzu fikri Rusya'da oldukça yeni olup 7-8 sene öncesine dayanmaktadır. Sadece Leningrad'da (St. Petersburg) altı büyük 55 küçük oyun parkı bulunmakta, bunların her yerinde kum yığınları yer almaktadır. Fakat yığınların belirli bir düzeni yoktur. Kum yığınlarının yanında çocukların kötü havalarda gidebilecekleri kapalı alanlar da bulunmaktadır. Kışın karlar kumları örttüğü için çocuklar kum yerine kar ile oynamaktadirlar.

\section{SONUÇ VE ÖNERILER}

\section{Sonuç}

Nitel bir yaklaşımla yapılandırılmış olan bu çalışmada elde edilen bulgular yaklaşık yüz yıl öncesinde Osmanlı ve Avrupalı aydınların çocuğa bakışı üzerine bilgi vermektedir. Gerek Avrupalı aydınlar gerekse Osmanlı aydınları çocukluğu yaşamın ayrı bir kutbu ve geleceğin umudu olarak görmüşler, çocukların sağlıklı yetiştirildiği takdirde topluma faydalı insanlar olacaklarını, bu nedenle yatırım yapılması gereken varlıklar oldukları fikrini savunmuşlardır. Öte yandan çocukların kendi haklarının olduğunu ve bu haklar arasında sağlıklı beslenme, temel bakım hizmetleri, korunma, temiz hava ve oyunun da yer aldığını belirtmiş; bu konularda birtakım politikalar geliştirilmesi gereği üzerinde durmuşlardır.

Eğlendirici ve keyif veren bir oyuncak olarak nitelendirilen kum, hem ucuz hem de sağlıklı bir malzemedir. Yapılan analiz sonucunda kumla oynamanın çocuklarda zihinsel, sosyal ve bedensel gelişimi desteklediği görüşü ortaya çıkmıştır. Öyle ki kum, hem bireysel becerileri geliştirmekte hem de birlikte oynandığı sürece yardımlaşma ve problem çözme becerilerini çocuğa kazandırarak sosyal gelişimini desteklemektedir. Öte yandan dikkatini toplamak, konsantre olmak, bir işe başlamak ve o işi bitirmek için sabır göstermek, yeni fikirler ortaya atmak gibi beceriler de kum aracılığı ile kazanılmakta ve zihinsel gelişime katkı koymaktadır. Bunlara ek olarak kumla oynayan çocuk yaratıcı bir sürece girmekte ve yaratıcılığı kum oyunları sayesinde gelişmektedir. Bu oyunlar süresince de duygularını kontrol etmeyi öğrenmekte ve sakinleşmektedir. Son olarak çocuk kumlarla oynarken yaptığı hareketler ile küçük kaslarını geliştirmekte, el becerileri kazanmakta ve kumda oynamanın kemiklerde yarattığı güçlenme ile beden sağlı̆̆

* Kitabın yazıldı̆̆g yıl düşünüldüğünde bu tarihin 1900'lerin başı olduğu anlaşılmaktadır. 
diğerlerine göre daha iyi olmaktadır. Tüm bu özelliklerinden yola çıkarak kumun bir eğitim aracı olarak kullanılması gerekliliği üzerinde durulmuştur.

Çocukların gelişimlerine büyük katkısı olan kumun ulaşılabilir bir materyal olması gerekmektedir. Bu nedenle geniş alanlarda, genel kullanım alanlarında, mahallelerde, parklarda ve bahçelerde çocuklar için kum oyun alanları yaratmakta fayda vardır. Çocuklar bu alanlarda temiz hava almak ve güneşten faydalanmanın yanı sıra hareket ihtiyaçlarını da giderebileceklerdir. Kum oyun alanlarının toplu yerleşim yerlerine yakın, cadde kalabalığından uzak fakat aynı zamanda da kolay ulaşılabilir yerlerde olması gerekmektedir. Bu alanlardaki kumların tahta kenarlıklı sandıklar içerisinde yer alması kumun muhafaza edilmesini de kolaylaştıracaktır. Öte yandan kumların yuvarlak taneli olması ve keskin maddelerden arındırılması; temiz ve yıkanmış olması; toprak ile karışmaması ve sık sık değiştirilmesi de sağlık açısından gereklidir. Belediyelerin kum alanlarını düzenlerken bu koşullara dikkat etmesi ve kumu yağmur, güneş ve sıcaktan korumak için üzerini örtmesi gerekmektedir.

Farklı ülkelerde kum oyun alanlarının düzenlenmesine yönelik görüşlere yer verilen Kumlarda Çocuk Oyunları adlı kitapta özellikle Almanya'daki çalışmalar üzerinde durulmuştur. 1890 yılında Alman İmparatoru ve Prusya Kralı Kaiser II. Wilhelm'in Berlin'de düzenlenen bir eğitim kongresinde yapmış olduğu çağrı ülke genelinde büyük yankı uyandırmış ve kum havuzları ile ilgili çalışmalar hızlandırılmıştır. Öyle ki ülke genelindeki belediyelere sorular gönderilmiş ve 173 belediyenin cevap vermesi ile kum oyun alanlarının toplamda 100,000 metrekarelik bir alanı kapladığ1; özellikle Breslav, Kasel, Geminç, Dortmiştad, Dresden, Frankfurd, Hamburg, Hanover, Münih ve Çivikar belediyelerinin kum alanları ile ilgili çalışmalara ilgi gösterdiği ve bu şehirlerde kum oyun alanlarına yer verildiği saptanmıştır. Almanya'ya benzer bir şekilde Danimarka da kum oyun alanları ve bu alanların düzenlenmesi konusunda diğer ülkelere göre daha ileridedir. Öte yandan Hollanda'daki kum havuzlarının varlığı da diğer ülkelere göre 2025 yıl öncesine dayanmaktadır. Macaristan'da kum oyun alanları çocuk ve ailelerin hoşuna gitmekte, fakat kum havuzlarının sayısının oldukça az olduğu belirtilmiştir. Benzer bir duruma İsviçre'de de rastlanılmış, Zürih'te okul bahçelerinde kumlu çakıl kullanılırken kumun eğitimde büyük rol oynamadığı görüşünün de yaygın olduğu bildirilmiştir. Son olarak Belçika ve Rusya'da kum havuzu fikrinin oldukça yeni olduğu ve bu ülkelerdeki kum oyun alanlarının sayısının da az olduğu belirtilmiştir.

\section{Öneriler}

Araşıırma kapsamında incelenen Kumlarda Çocuk Oyunları adlı eser yazıldığı dönem içerisinde çocuğa bakış, kumun bir eğitim aracı olarak kullanılması, kum oyun alanlarının düzenlenmesi ve farklı ülkelerde kum oyun alanları konularında okuyucuya bilgi vermektedir.

Toplumun geleceği olan çocukların birtakım haklara sahip olduğu ve bu haklar arasında oyunun da bulunduğu geçtiğimiz yüzyıl içerisinde tartışılmış ve bu konuda çeşitli politikalar üretilmiştir. Ne yazık ki günümüzde halen daha birçok çocuk, oyunun onun temel haklarından birisi olduğunu bilmemekte, oyundan mahrum edilmekte veya elverişsiz ortamlarda oyun oynamaya mahkum edilmektedir. Şüphesiz bu konuda yetişkinlerin bilgi eksikliği içerisinde olmalarının da etkisi vardır. İçerisinde bulunduğumuz yüzyılda yapılan çalışmalara rağmen halen daha çocuğa bakışımız değiş̧memişse ve onlara karşı hak ihlali yapıyorsak bu toplumsal bir sorundur. Bu sorunu 
aşabilmek için çocuk hakları konusunda daha fazla çalışmalı, yapılan çalışmalar daha geniş kitlelere iletilmeli, gerekirse yetişkin eğitimleri yaygınlaştırılmalıdır.

Günümüzde çocuk oyun alanlarının düzenlenmesi ile ilgili çeşitli çalışmalar yapılmakta, çocuğa en az zarar verici maddeler seçilerek bu alanlar düzenlenmektedir. Fakat tüm bunları yaparken çocuğun doğal malzemelerden uzaklaştırıldığı söylenebilir. Kum, çocukların gelişim alanlarını desteklemekle beraber ekonomik ve kolay bulunan bir malzemedir. Bunun yanı sıra çocuğu doğa ile yakınlaştırır. Dolayısı ile kumun oyun alanları ve okul bahçelerinde daha yaygın bir şekilde kullanılması; bunu yaparken de hijyenik koşulların sağlanması önerilmektedir.

Türkiye ile kıyaslandığında Avrupa'da kum ile ilgili çalışmaların çok öncelere dayandığı görülmektedir. Özellikle Almanya'da çocuk oyun alanlarının düzenlenmesi ve bu alanlarda kumun kullanılması milli bir dava haline getirilmiş ve bu konuda ciddi çalışmalar yürütülmüş̧ür. Kumlarda Çocuk Oyunları adlı kitabın yıllar önce Osmanlıcaya çevrilmiş olması, yine o yıllarda Küçüklere Çamur İşlerini Nasıl Yaptırmal1, Evde Mektep: Oyuncaklar ve Yeni Mektebin Ders Vasitalarından Kum gibi eserlerin literatüre kazandırılması o yıllarda Türkiye'de bu tür çalışmalara önem verildiğinin bir göstergesidir. Fakat günümüz ile kıyaslandığında kum havuzlarının göz ardı edildiği ve kumların eğitici bir araç olabileceği fikrinden uzakta olduğumuz görülmektedir. Bu hususta yeni düzenlemeler yapılarak kum oyunlarının eğitimde daha aktif bir şekilde kullanılması önerilmektedir.

Son olarak belediyelerin çocuk dostu kentler yaratmak için daha fazla proje üretmesi, bu projelerde çocuk konusunda çalışan işinin ehli kişilere yer vermesi, üretilen projeleri desteklemesi ve çocukları hem doğa ile buluşturan hem de gelişim alanların destekleyen oyun alanlarına kavuşturması öneriler arasındadır. 


\section{KAYNAKÇA}

Ali, S. (2016). Sırça köşk. İstanbul: Yapı Kredi Yayınları.

And, M. (2012). Oyun ve bügü. İstanbul: Yapı Kredi Yayınları.

Aral, N., Gürsoy, F. ve Köksal, A. (2001). Okul öncesi eğitimde oyun. İstanbul: YA-PA Yayınları.

Ayaydın, A. (2011). Çocuk gelişiminde bir oyun olarak sanat ve resim. Elektronik Sosyal Bilimler Dergisi, 10(37), 303-316.

Baytal, Y. (2009). Atatürk döneminde nüfusu artırma çalışmaları ve gürbüz Türk çocuğu projesi. Cumhuriyet Tarihi Araştırmaları Dergisi, 5(10), 117-137.

British Adventure Play (n.d.). The history of adventure play. Retrieved November 7, 2016, from http://www.adventureplay.org.uk/history2.htm.

Çakırer Özservet, Y. (2015a). Türkiye'de çocuk ve şehir ilişkisi üzerine yapılmış akademik çalışmaların değerlendirilmesi. Y. Çakırer Özservet ve Ezgi Küçük (Ed.), Çocukların şehri üzerine içinde (s. 18-47). İstanbul: Marmara Belediyeler Birliği Kültür Yayınları.

Çakırer Özservet, Y. (2015b). Çocuk dostu belediyecilik. Illler ve Belediyeler Dergisi, 1(802), 38-43.

Çukur, D. (2009) Çocuk dinlenimi açısından oyunun önemi ve konut yakın çevresinde oyun değerini artırıcı mekansal düzenlemeler, Ege Mimarlık, 69, 14-17.

Çukur, D. (2011). Okulöncesi çocukluk döneminde sağlıklı gelişimi destekleyici dış mekân tasarımı. SDÜ Orman Fakültesi Dergisi, 12, 70-76.

Çukur, D. ve Özgüner, H. (2008). Kentsel alanda çocuklara doğa bilinci kazandırmada oyun mekân tasarımının rolü. SDÜ Orman Fakültesi Dergisi, 2, 177-187.

Dirim, A. (2000). Illköğretim okulları için çocuk oyunları. İstanbul: Esin Yayınevi.

Durualp, E. ve Aral, N. (2010). Altı yaşındaki çocukların sosyal becerilerine oyun temelli sosyal beceri eğitiminin etkisinin incelenmesi. Hacettepe Üniversitesi Ĕ̆itim Fakültesi Dergisi, 39, 160-172.

Egeli, M. H. (1927). Çocuk nasıl ve ne ile oynamalıdır? Ankara: Hâkimiyet-i Milliye Matbaasi.

Egemen, A., Yılmaz, Ö. ve Akil, İ. (2004). Oyun, oyuncak ve çocuk. ADÜ Tıp Fakültesi Dergisi, 5(2), 39-42.

Ekmekçi, P. E., Arda, B. ve Acıduman, A. (2012). Tıp tarihi açısından çocuk esirgeme kurumunun kuruluş dönemi etkinliklerine bir kitap bağlamında bakış: Büyük çocukların çeslenme usülleri (1927). Çocuk Să̆lı̆̆l ve Hastalıkları Dergisi, 55 (1), 57-69.

Fabes, R. A.; Hanish, L. D.; Martin, C. L; Eisenberg, N. (2002). Young children's negative emotionality and social isolation: A latent growth curve anlaysis. Merrill Palmer Quarterly, 48(3), 284-307.

Fanuscu, E. M. (1994). Çocuk oyun alanları. İstanbul Üniversitesi Orman Fakültesi Dergisi, 44(1-2), 145-154.

Garcin, F. (1914). Çocuklara çamur işlerini nasıl yaptırmalı? (A. Ulvi, Çev.) İstanbul: Matbaa-i Amire. (Orjinal çalışmanın yayınlandığı yıl bilinmemektedir.)

Gökmen, H. S. (2006). Konutta çocuk var mı?. Ege Mimarlık, 2(57), 22-25. 
Gül, M. (2006). Anasınıfina devam eden alt sosyo-ekonomik düzeydeki 61-72 ay arası çocuklara sembolik oyun eğitiminin genel gelişim durumlarına etkisi. Yayımlanmamış Yüksek Lisans Tezi, Gazi Üniversitesi, Ankara.

Hilmi, A. (1928). Kumlarda çocuk oyunlart. İstanbul: Devlet Matbaası.

Hughes, F. P. (2010). Children, play and development (4th ed). California: SAGE Publications.

Karaküçük, S. A. (2008). Okul öncesi eğitim kurumlarında fiziksel/mekânsal koşulların incelenmesi: Sivas ili örneği. CÜ Sosyal Bilimler Dergisi, 32(2), 307-320.

Kaya, D. (2007). 36-72 aylık çocuklar için tasarlanmış oyuncakların çocukların gelişim alanlarına göre incelenmesi. Yüksek lisans tezi, Gazi Üniversitesi, Ankara.

Kıran, B., Çalık, C. ve Esenay F. I. (2013). Terapotik oyun: Hasta çocuk ile iletişimin anahtarı. Ankara Sağllk Bilimleri Dergisi, 2(1-2-3), 1-10.

Koçyiğit, S., Tuğluk, M. N. ve Kök, M. (2007). Çocuğun gelişim sürecinde eğitsel bir etkinlik olarak oyun. Kazım Karabekir Eğitim Fakültesi Dergisi, 16, 324-342.

Kunsthalle Zürich (n.d.). Das spielen im sand. Retrieved November 7, 2016, from http://kunsthallezurich.ch/en/articles/das-spielen-im-sand.

Kültür Bakanlığı (1934). Yeni mektebin ders vasitalarından kum. İstanbul: Devlet Basımevi.

Lincoln, Y. S. \& Guba, E. G. (1985). Naturalistic inquiry. London: Sage.

Mayes, C., Blackwell Mayes, P. \& Williams, E. (2007). Messages in the sand: Sandtray therapy techniques with graduate students in an educational leadership program. International Journal of Leadership in Education Theory and Procatice, 7 (3), 257-284.

Özdil, G. (2008). Kişilerarası problem çözme becerileri eğitimi programının okul öncesi kurumlara devam eden çocukların kişilerarası problem çözme becerilerine etkisi. Yayımlanmamış Yüksek Lisans Tezi, Adnan Menderes Üniversitesi, Aydın.

Özgen, Y. (1997). Eğitim kurumlarındaki oyun çağı çocukların bahçe donatıları ve araçları üzerine bir araştırma. İstanbul Üniversitesi Orman Fakültesi Dergisi, 47(1), 31-50.

Özgüç Erdönmez, İ. M. (2007). İlköğretim okulu bahçelerinde peyzaj tasarım normları. İstanbul Üniversitesi Orman Fakültesi Dergisi, 57(1), 107-122.

Öztürk, A. (2015). Çocuğun dünyasında sokak. Y. Çakırer Özservet ve E. Küçük (Ed.), Çocukların Şehri Üzerine içinde (s. 49-65). İstanbul: Marmara Belediyeler Birliği Kültür Yayınları.

Pulaski, M. A. S. (1970). Play as a function of toy structure and fantasy predisposition. Child Development, 41(2), 531-537.

Singer, J. (1994). Imaginative play and adaptive development. In J. H. Goldstein (Eds), Toys, Plays and Child Development (pp. 6-26). Cambridge: Cambridge University Press.

Susüzer, K. (2006). Oyun yoluyla Fransızca öğretimi. Yayımlanmamış Yüksek Lisans Tezi, Çukurova Üniversitesi, Adana. 
Şar, E. (2015). Antik Yunan'da çocuk oyuncakları ve oyuları. Oyun Yaşam ve Eğitim, 1, 14-17.

Terr, L. (2000). Sevgi ve çallşmanın ötesinde oyun yetişkinler için neden ihtiyaçtır? (M. Köseoğlu, Çev.). İstanbul: Literatür Yayıncılık. (Orjinal çalışma 1999 yılında yayımlanmıştır)

Türkan, E. E. (2009). Balıkesir kenti çocuk oyun alanlarının irdelenmesi. Yayımlanmamış Yüksek Lisans Tezi, Selçuk Üniversitesi, Konya.

Türkiye Himaye-i Etfal Cemiyeti (t. y.). 24 saatte çocuk bakımı, Türkiye Himaye-i Etfal Cemiyeti Yardım Kartı.

Türkiye Himaye-i Etfal Cemiyeti (t. y.). Çocuk nerede uyumalı, Türkiye Himaye-i Etfal Cemiyeti Yardım Kartı.

Ulutaş, A. (2011). Okul öncesi dönemde drama ve oyunun önemi. Adlyaman Üniversitesi Sosyal Bilimler Enstitüsü Dergisi, 4(6), 233-242.

UNICEF (2016). Çocuk Haklarına Dair Sözleşme 28.11.2016 tarihinde https://www.unicef.org/turkey/crc/_cr23c.html adresinden alınmıştır.

Ummanel, A. (2007). Okul öncesi çocuklarda akran kabulünün çeşitli değişkinler açısından incelenmesi. Yüksek lisans tezi, Ankara Üniversitesi, Ankara.

Ummanel, A. (2017). Türkiye Himaye-i Etfal Cemiyeti yayınlarından bir kartpostalın çocuk hakları bağlamında incelenmesi. Illkögretim Online, 16(1), 245-255.

Umut Vakfı (2003, Eylül). "Oyuncak hakkında yönetmelik" hakkında çalışma komisyonu raporu. 15.10.2016 tarihinde http://www.umut.org.tr/umut-vakfioyuncaklar-hakkinda-yonetmelik-hakkinda-calisma-komisyonu-raporu/ adresinden alınmıştır.

Yıldırım, A. (1999). Nitel araştırma yöntemlerinin temel özellikleri ve eğitim araştırmalarındaki yeri ve önemi. Ĕgitim ve Bilim, 23(112), 7-17.

Yıldırım, A. ve Şimşek, H. (2008). Sosyal bilimlerde nitel araştırma yöntemleri. Ankara: Seçkin.

Yörükoğlu, A. (1987). Çocuk ruh sağllğg. Ankara: Türkiye İş Bankası Kültür Yayınları.

Yücel, G. F. (2005). Çocuk oyun alanları tasarımı. İstanbul Üniversitesi Orman Fakültesi Dergisi, 55(2), 99-110.

Zekeriya, S., Halim, B. ve Zekeriya, M. (1927). Evde mektep: Oyuncaklar. İstanbul: Resimli Ay Matbaas1.

Zengin, F. (2001). İlköğretim okullarında açık alan performansının değerlendirilmesi ve okul oyun alanları için tasarım kriterleri. Yayımlanmamış Yüksek Lisans Tezi, İstanbul Teknik Üniversitesi, İstanbul. 


\section{EXTENDED ABSTRACT}

\section{Introduction}

Playing games, which is the primary action of children, is the sum of activities that occurs spontaneously without any pressure and influence children's all developmental areas including their cognitive, linguistic, social, emotional, motor developmental, and selfcare abilities. Although children initially play alone, over time, they start to play collaborative games with their friends during the socialization process. These games can take place both indoors as well as outdoors. Because of their nature, outdoors are playgrounds where children can act more freely, and their motor skills are supported at the highest level. In addition, children are directed to activities that commune them with the environment; while they find an opportunity to make activities in fresh air, their environmental consciousness increases as well.

Many studies that are oriented at constructing outdoor playgrounds in a manner to support children's developmental areas are being carried out both in our country and throughout the world and with respect to the use of these areas, care is being taken to use materials that will not harm children. Certainly, one of these materials is sand, which supports the creativity, fine motor skills and the social development of children. The concept of using sand as an educational tool has a quite long history. Such that, it is possible to encounter information on sand games in pedagogic books that were translated to Ottoman Turkish as a result of the influence of Westernization that took place at the beginning of the $20^{\text {th }}$ Century. One of these books is the Children's Games in Sand that was published in Europe in 1909 and translated to Ottoman Turkish in 1928 by the education inspector of the period, Ahmet Hilmi.

The purpose of this study is to analyze the book Children's Games on Sand, which was translated from a foreign language to Ottoman Turkish and was one of the studies carried out on the importance of sand pits, during the first years of the foundation of the Turkish Republic.

\section{Method}

The translation and back translation of the book that was discussed in the study were made by two experts with commands of Turkish and Ottoman Turkish and the opinion of a third expert was taken. In this qualitative study, document analysis was used to analyze the data. Data was collected under themes that were designated during the analysis process and then were analyzed.

Categories that were generated in the analysis process were classified under four headings such as Overview of Child, Sand as an Educational Tool, Organization of Outdoor Playgrounds, and Sand Play Areas in Different Countries.

\section{Findings and Discussion}

The findings of this study provide information about the perspectives of Ottoman and European intellectuals on children about a century ago. Both European and Ottoman intellectuals have considered childhood as a different part of life and beacon of hope for the future and maintained that children would be of service to the society if they were brought up in a healthy manner and therefore we should invest in them. Furthermore, they claimed that children have their own rights and such rights contain healthy diet, 
basic care services, protection, clean air, and playing, and we should develop a set of policies about such matters.

Being described as an entertaining and joyful activity, the sand is a cheap and healthy material. The analysis indicates that playing with sand supports the mental, social and physical development of the children. So much so that sand develops both individual skills and brings in cooperation and problem-solving skills for the child as long as it is played together with other children and thereby supporting the social development. Moreover, the sand provides skills such as gathering attention, concentrating, starting a new work and showing patience to finish such work and bring up new ideas, and contributes to the mental development. In addition, playing with the sand, the child enters a creative process, and his/her creativity develops through sand games. During these games, the child learns to control his/her emotions and calms down, develops his/her small muscles through movements and acquires hand skills. By taking these features into consideration, while organizing an activity, the sand should be used as a tool for education.

Sand has a great contribution to the development of children, and it is an accessible material. Therefore, it is important to create sand playgrounds for children to play in wide spaces, neighborhoods, parks, and gardens. These playgrounds should be easily accessible, close to the collective settlement areas and distant from the crowded streets. The sand will be easily preserved if they are kept in the wooden cases in such spaces. Furthermore, the sand should be clear of sharp materials and have around grains, be clear and washed, not mixed with soil and frequently be changed for health aspects. The municipalities should take these conditions into account while organizing the sand spaces and cover the sand to protect it from the rain, sun, and heat.

A book titled as Children's Games on Sand, which provides information about the opinions on organizing the sand playgrounds in different countries, particularly emphasizes the studies in Germany. In 1890, German Emperor and King of Prussia, Kaiser II. Wilhelm, made a tremendous impact across the country when they made a call in the education conference, held in Berlin and then the sandbox studies were increased in numbers. In fact, the people sent out questions to the municipalities all around the country, and it has been observed that sand playgrounds take up a 100.000 sqm space in total, and especially Breslau, Kasel, Geminç, Darmstadt, Dresden, Frankfurt, Hamburg, Hannover, Munich and Zwickau municipalities interested in the sand spaces and such cities give a place for the sand playgrounds. Like Germany, Denmark is more advanced than other countries on sand playgrounds and organizing such spaces. Moreover, the existence of sandboxes in Netherlands dates back to 20-25 years earlier in comparison to other countries. It has been stated that the children and families like the sand playgrounds in Hungary, however, there are few sandboxes. A similar situation was also observed in Switzerland, and it is widely accepted that the sand does not play an important role in education while sandy gravel is used in school gardens in Zurich. Finally, it is stated that the sandbox is a new idea in Belgium and Russia, and there are few sand playgrounds in these countries.

\section{Conclusion and Suggestions}

Today, there are several studies about organizing the playgrounds, and these spaces are organized by selecting the least damaging material for children. However, we can say 
that we draw away the children from the natural materials in doing so. The sand not only supports the development areas of the children but also it is a cost-effective and easy-tofind material. It also makes the children familiar with nature. Therefore, it is suggested that the sand should be used more widely in the playgrounds and school gardens, and hygienic conditions should be preserved in doing so.

The studies on sand are dated back to earlier times in Europe in comparison to Turkey. Organizing the playgrounds and using sand in such spaces in Germany has become a national cause and they have made significant studies about it. Translating the book titled as Children's Games on Sand into Ottoman and providing works to the literature such as How Children Do Mud Works, The School at Home: Toys, and Sand as a Course in the New School show that Turkey placed importance on such studies in those years. However, we can see that sandboxes are ignored, and we do not consider sands as an educative tool when we compare it with today's materials. It is suggested that sand games should be used more actively in education by making new regulations in that aspect.

Finally, the municipalities should create more projects, employ skilled people on children development in these projects and support such projects, and provide playgrounds that expose children to nature and support their development areas to create child-friendly cities. 